\title{
II. SEISMIC REFLECTION SURVEY OF LEG 29 DRILL SITES
}

\author{
Robert E. Houtz and T.D. Aitken, Lamont-Doherty Geological Observatory of \\ Columbia University, Palisades, New York
}

In the navigational plots shown in Figures 1-7, the ships' tracks in the area of each drill site are annotated with time marks that can be related to the times shown on the seismic profiler sections. The navigational plots appear in sequence, and each plot is followed by the profiler sections that appear in that particular plot. Sonobuoy station numbers are preceded by the letter $\mathbf{R}$ in the profiler photographs.

Sites 275,276 , and 278 were not surveyed as drill sites by Eltanin because sufficient profiler data were already available from previous Eltanin sections. Sites 277, 282, and 284 were chosen as entirely new sites during Leg 29 , but except for Site 277 (not shown), enough data were already available to obviate additional surveys.

The rest of the sites were surveyed in detail by Eltanin. The sonobuoy data from these surveys appear separately (Houtz, 1975). Note that the navigational control of Eltanin Cruise 27 and Conrad 9 is inferior to that of the other cruises. All the records were made with an airgun sound-source except on Eltanin 39, when a compressor breakdown necessitated the use of a $10-\mathrm{kj}$ sparker.

\section{ACKNOWLEDGMENTS}

With the exception of a Conrad-9 profiler section near Site 284, all the seismic data were obtained aboard Eltanin. These cruises were supported by the Office of Polar Programs, National Science Foundation. The detailed surveys at Sites $279,280,281$, and 283 were carried out under the direction of T. Aitken as Chief Scientist aboard Eltanin. Partial support for the data reduction was provided by National Science Foundation Grant GA 28338.

\section{REFERENCE}

Houtz, R.E., 1975. South Tasman Basin and borderlands: a geophysical summary. In Kennett, J.P., Houtz, R.E., et al., Initial Reports of the Deep Sea Drilling Project, Volume 29: Washington (U.S. Government Printing Office), p. 1135-1147. 


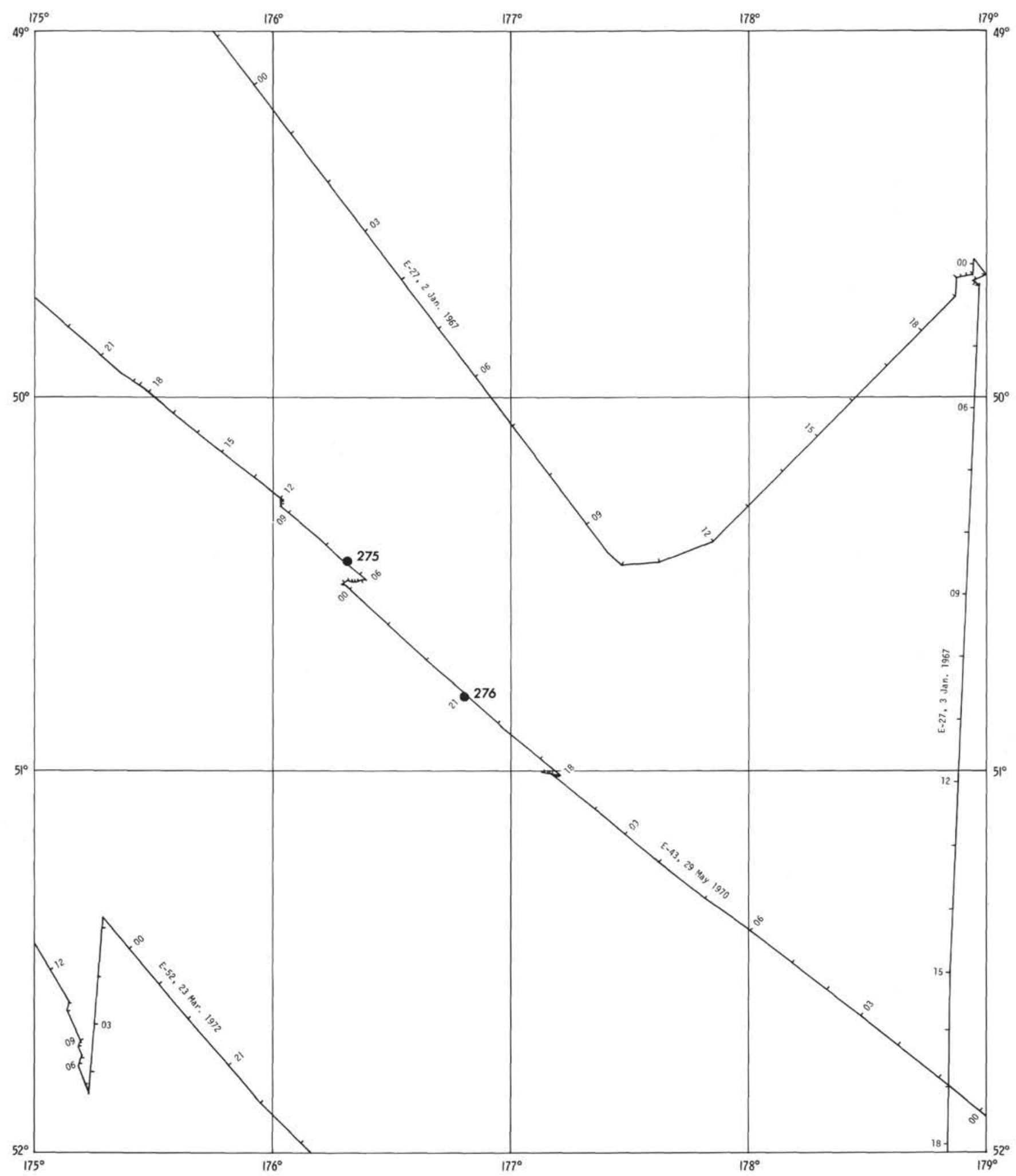

Figure 1. Track charts for Eltanin Cruises 27, 32, 43, and 52 in vicinity of Sites 275 and 276 DSDP Leg 29. 


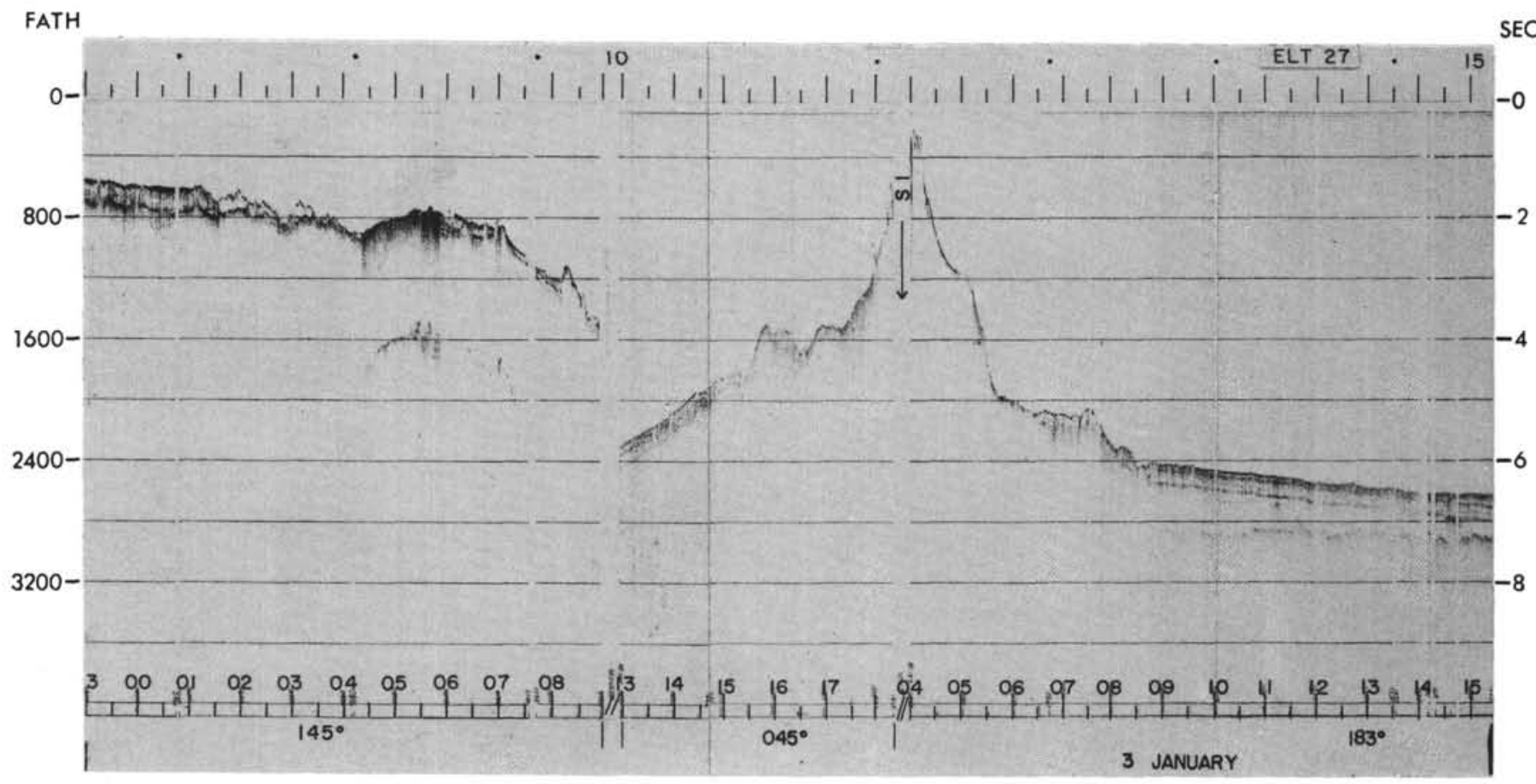

Figure 2. Eltanin 27, 32, 43, and 52 profiler records in vicinity of Sites 275 and 276, DSDP Leg 29. (a) Eltanin 27, 2300 hr, 1 January 1967 to $1400 \mathrm{hr}$, 4 January 1967.

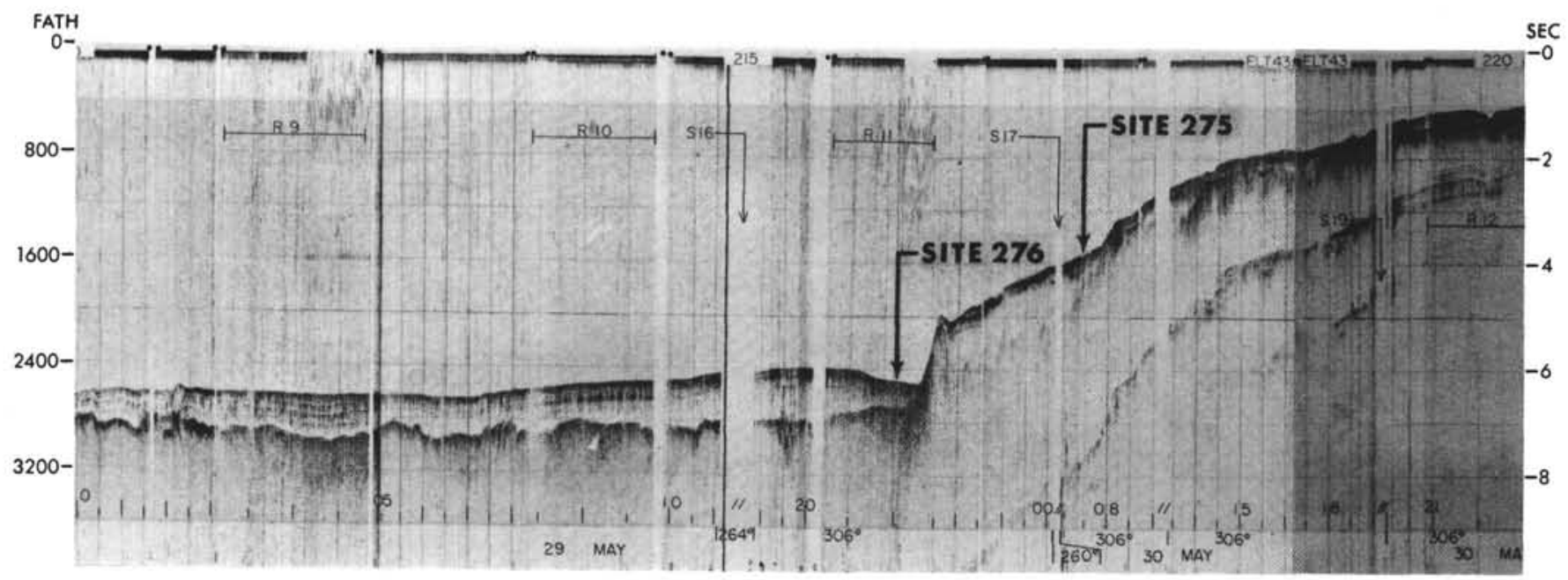

Figure 2b. Eltanin 43, 1930 hr, 29 May 1970 to 2200 hr, 30 May 1970. 
R. E. HOUTZ, T. D. AITKEN

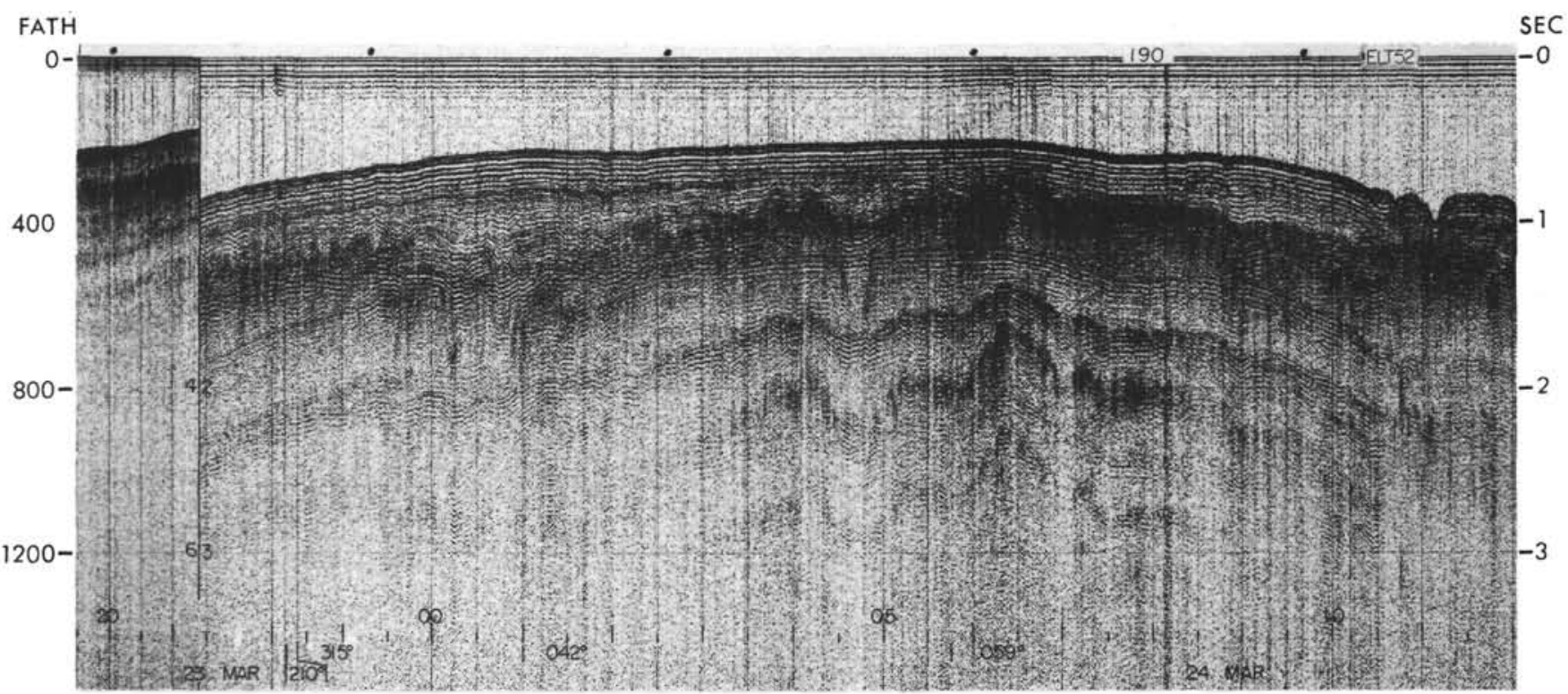

Figure 2c. Eltanin 52,1930 hr, 22 March 1972 to $1200 \mathrm{hr}, 24$ March 1972. 


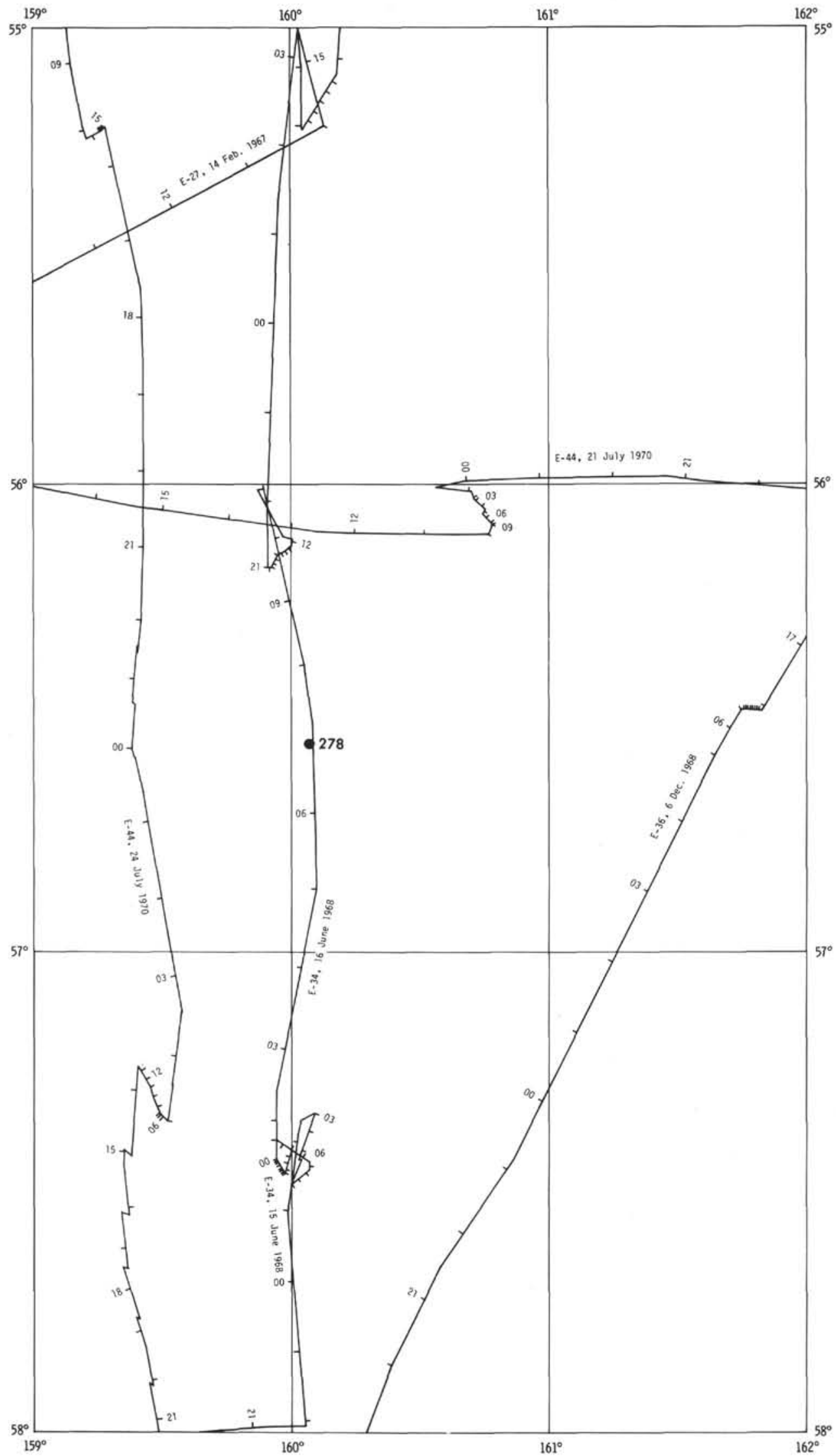

Figure 3. Track charts for Eltanin Cruises 27, 34, 36, and 44 in vicinity of Site 278, DSDP Leg 29. 


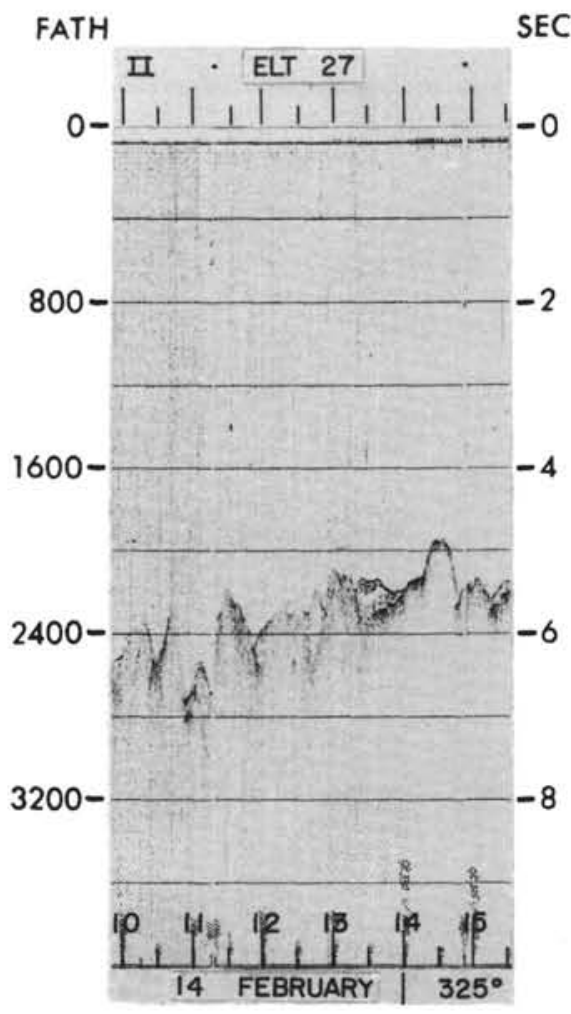

Figure 4. Eltanin 27, 34, 36, and 44. Profiler records in vicinity of Site 278, DSDP Leg 29. (a) Eltanin 27, $1000 \mathrm{hr}, 14$ February 1967 to 1500 hr, 14 February 1967.

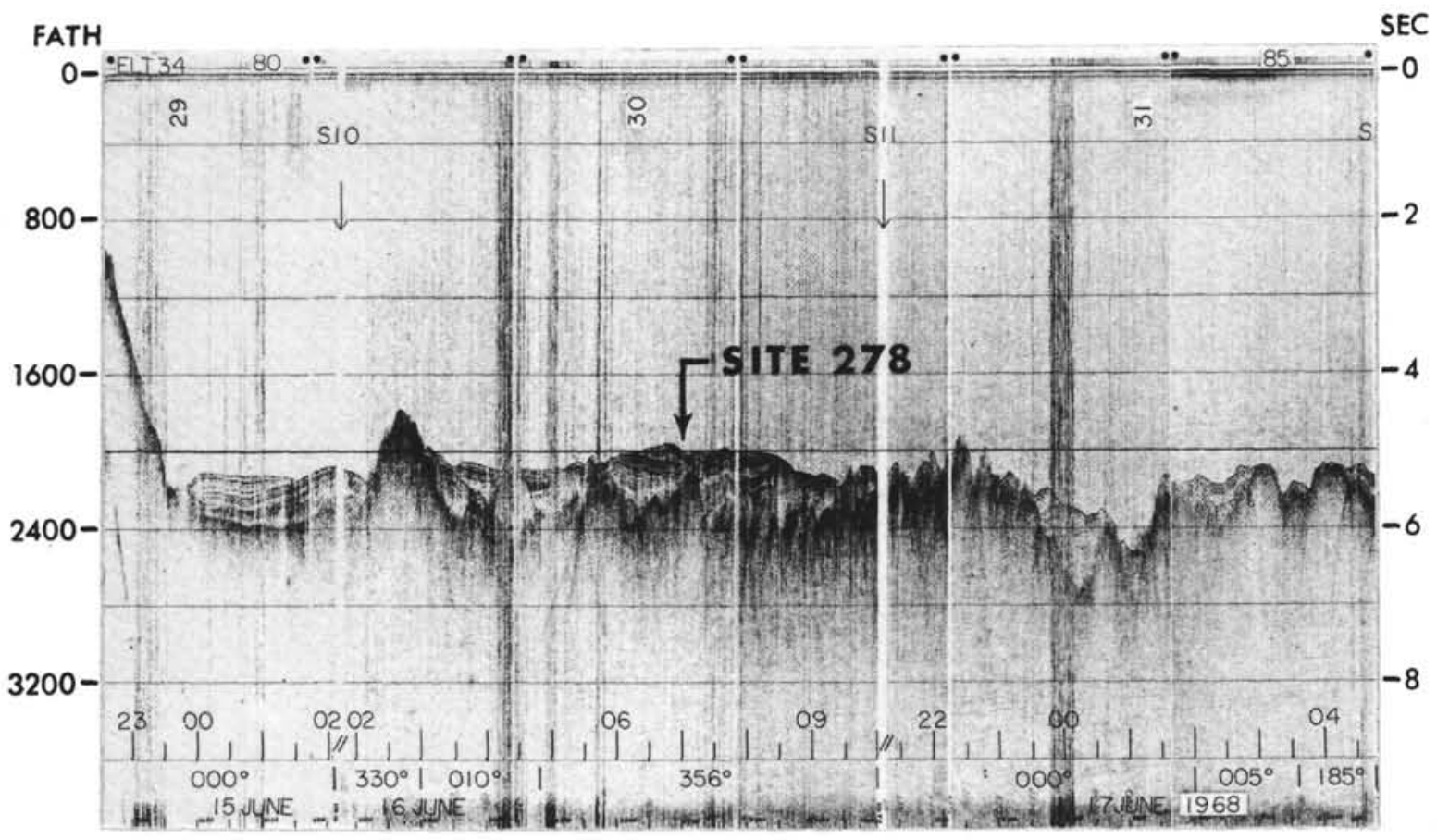

Figure 4b. Eltanin 34, 2300 hr, 15 June 1968 to 0430 hr, 17 June 1968. 


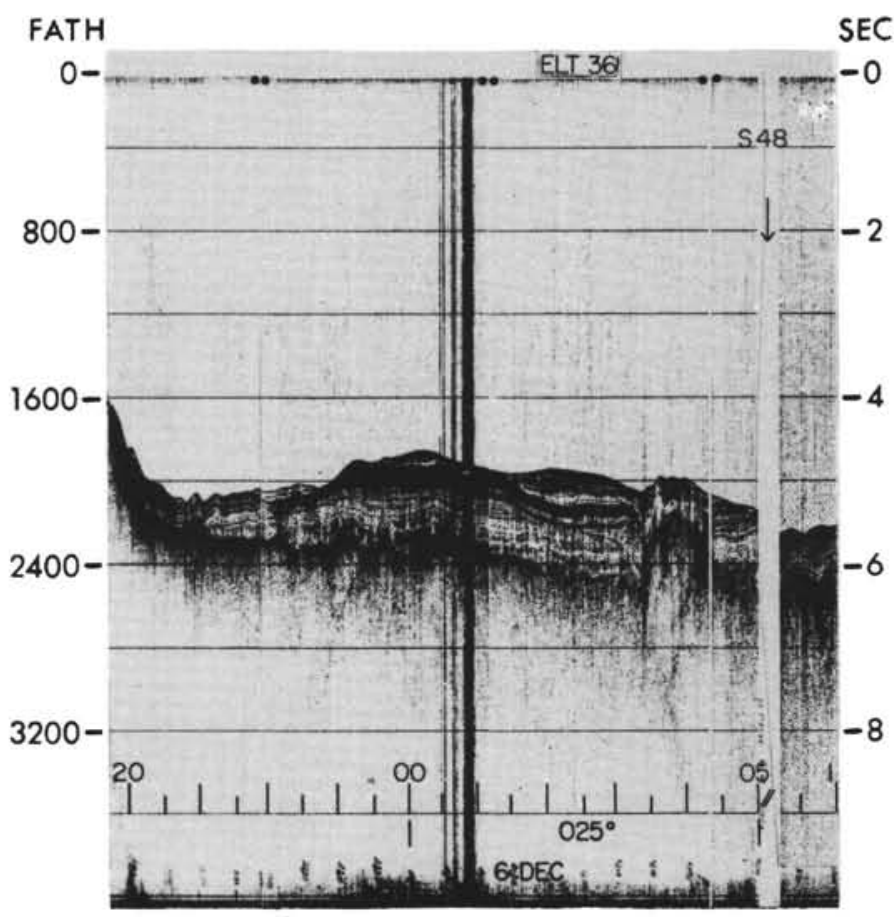

Figure 4c. Eltanin 36, $2000 \mathrm{hr}, 5$ December 1968 to $1700 \mathrm{hr}$, 6 December 1968.

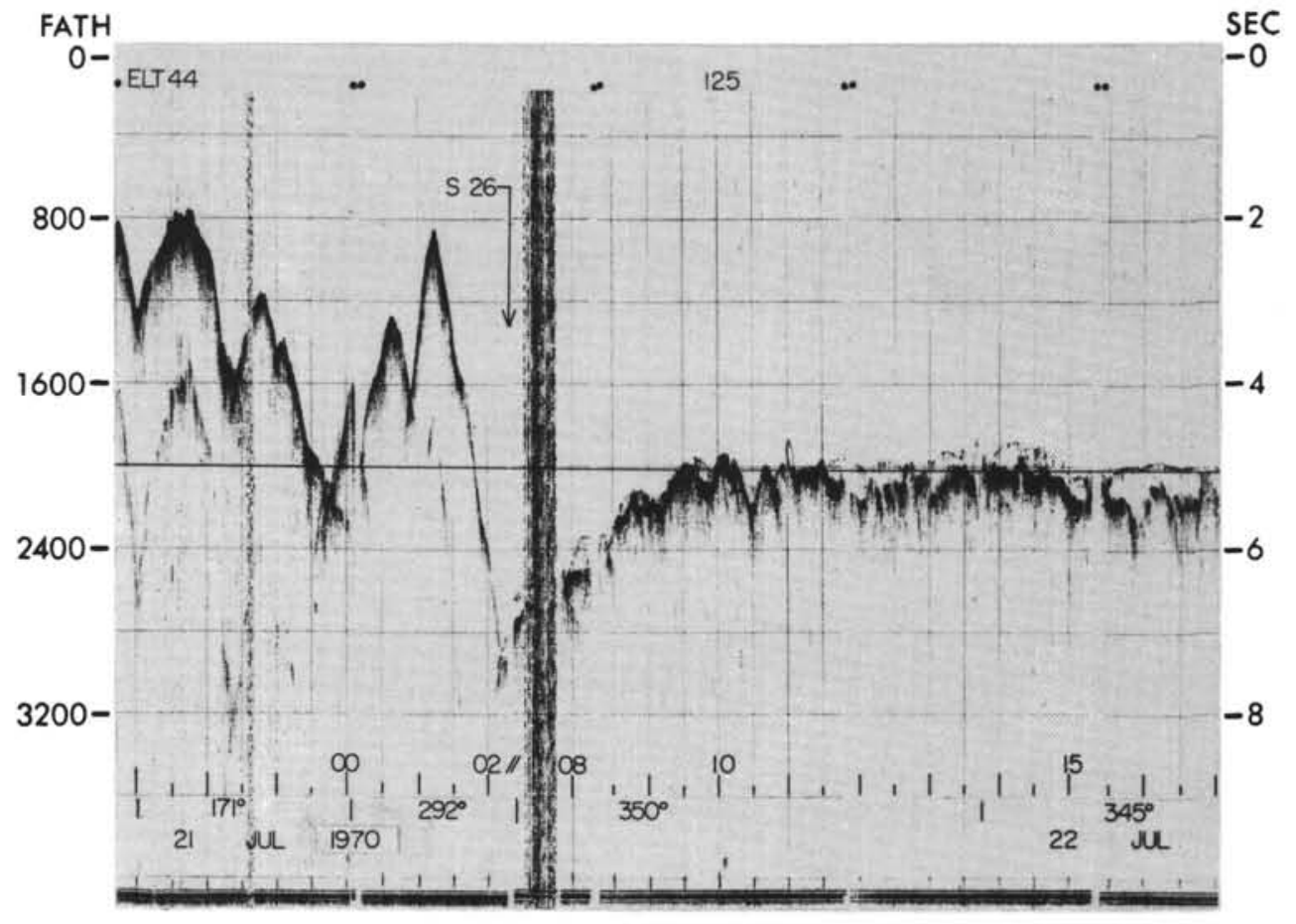

Figure 4d. Eltanin 44, $2100 \mathrm{hr}, 21 \mathrm{July} 1970$ to $1700 \mathrm{hr}, 22 \mathrm{July} 1970$; and $0900 \mathrm{hr}, 23$ July 1970 to $2100 \mathrm{hr}, 24$ July 1970. 
R. E. HOUTZ, T. D. AITKEN

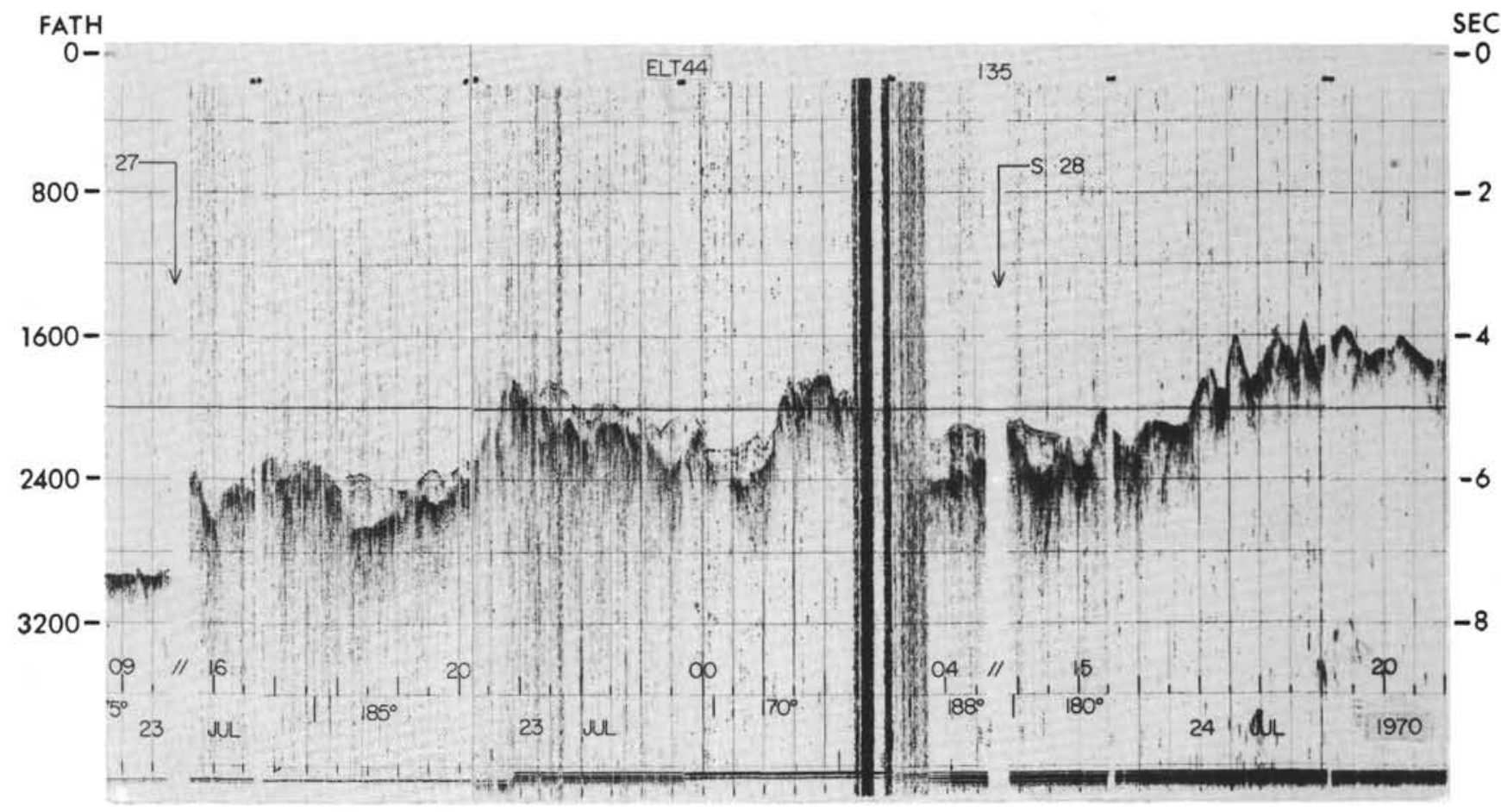

Figure 4d. (Continued). 


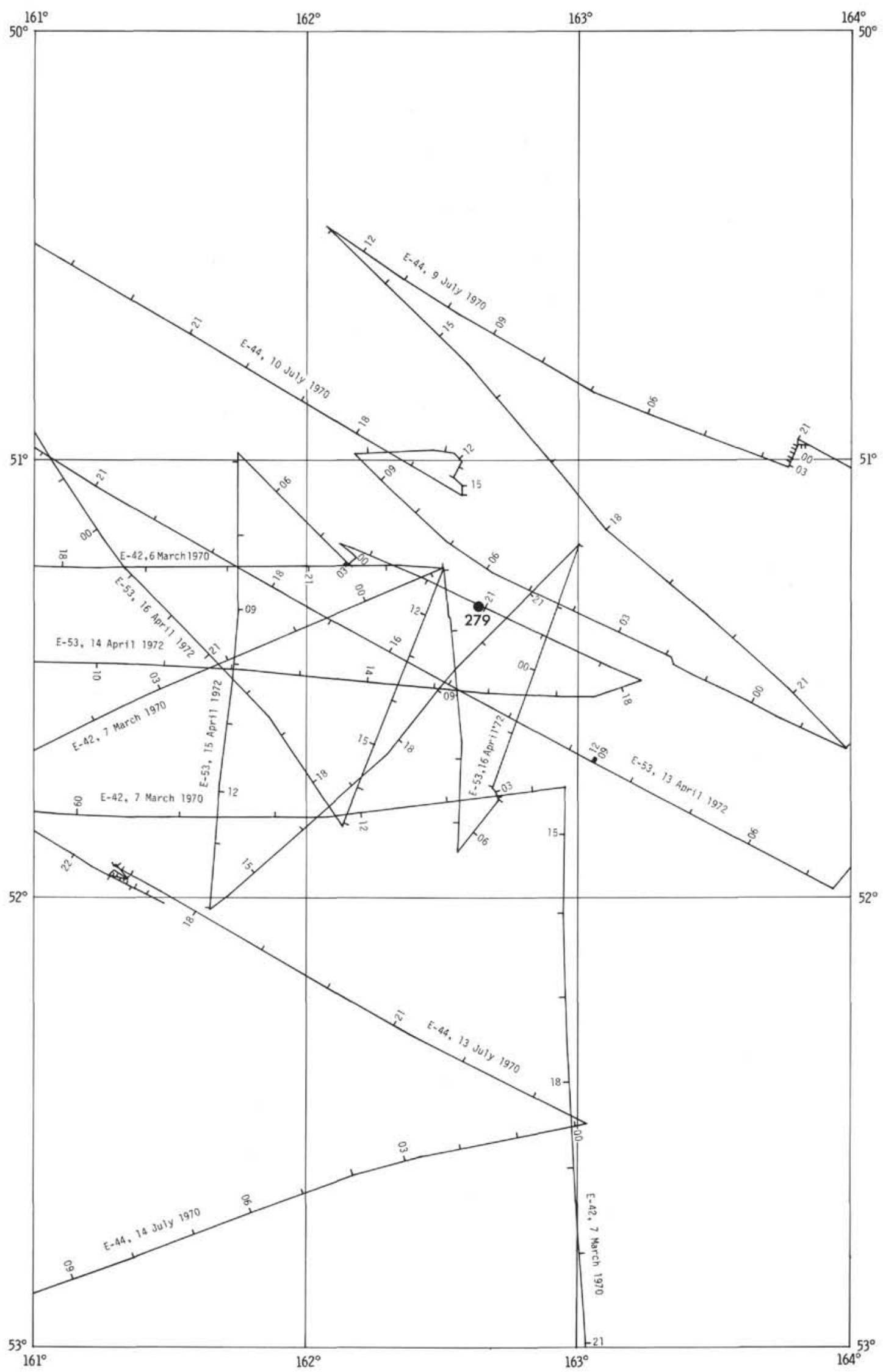

Figure 5. Track charts for Eltanin Cruises 42, 44, and 53 in vicinity of Site 279 DSDP Leg 29. 


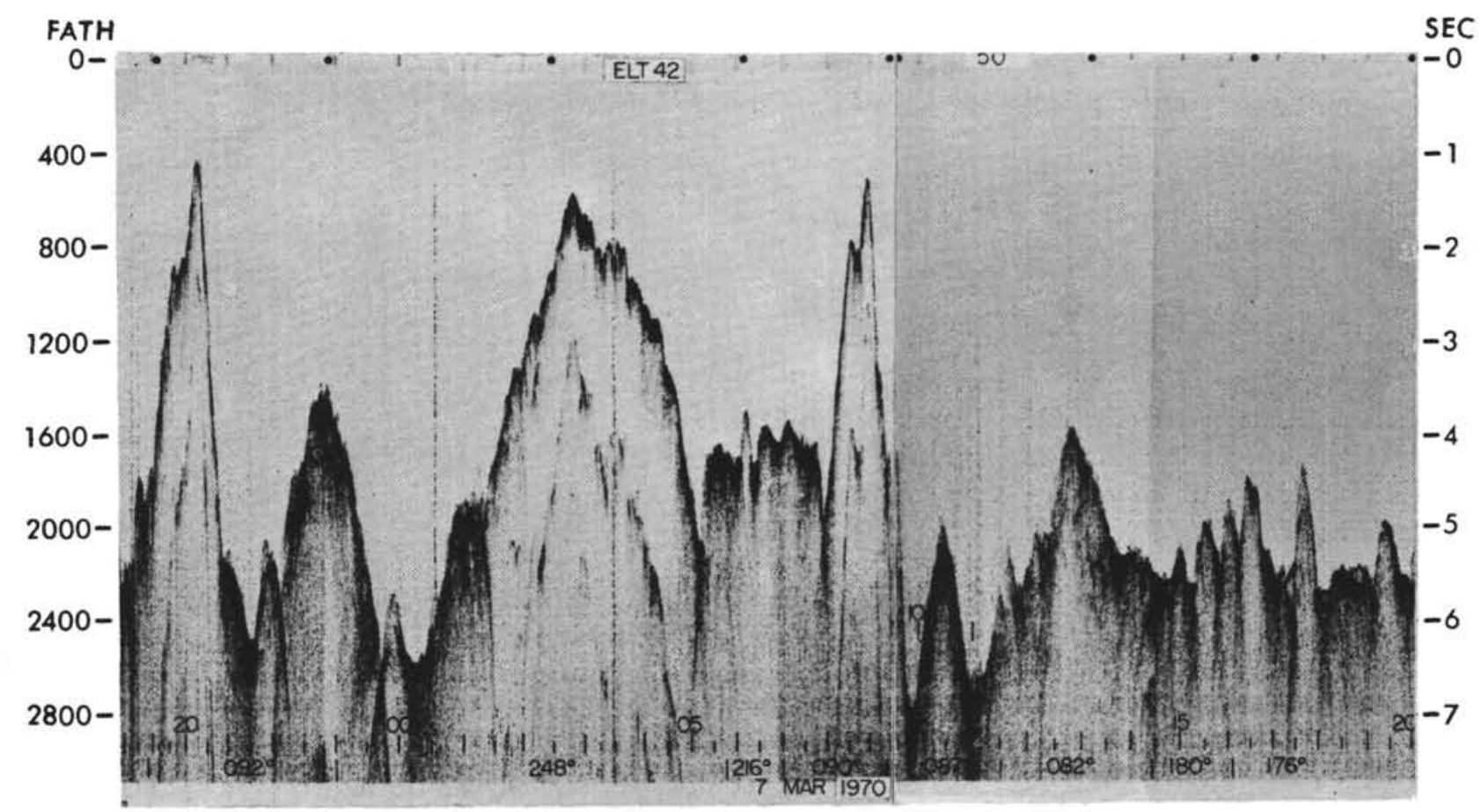

Figure 6. Eltanin 42, 44, and 53 profiler records in vicinity of Site 279, DSDP Leg 29. (a) Eltanin 42, $1800 \mathrm{hr}, 6$ March 1970 to $2000 \mathrm{hr}, 7$ March, 1970. 

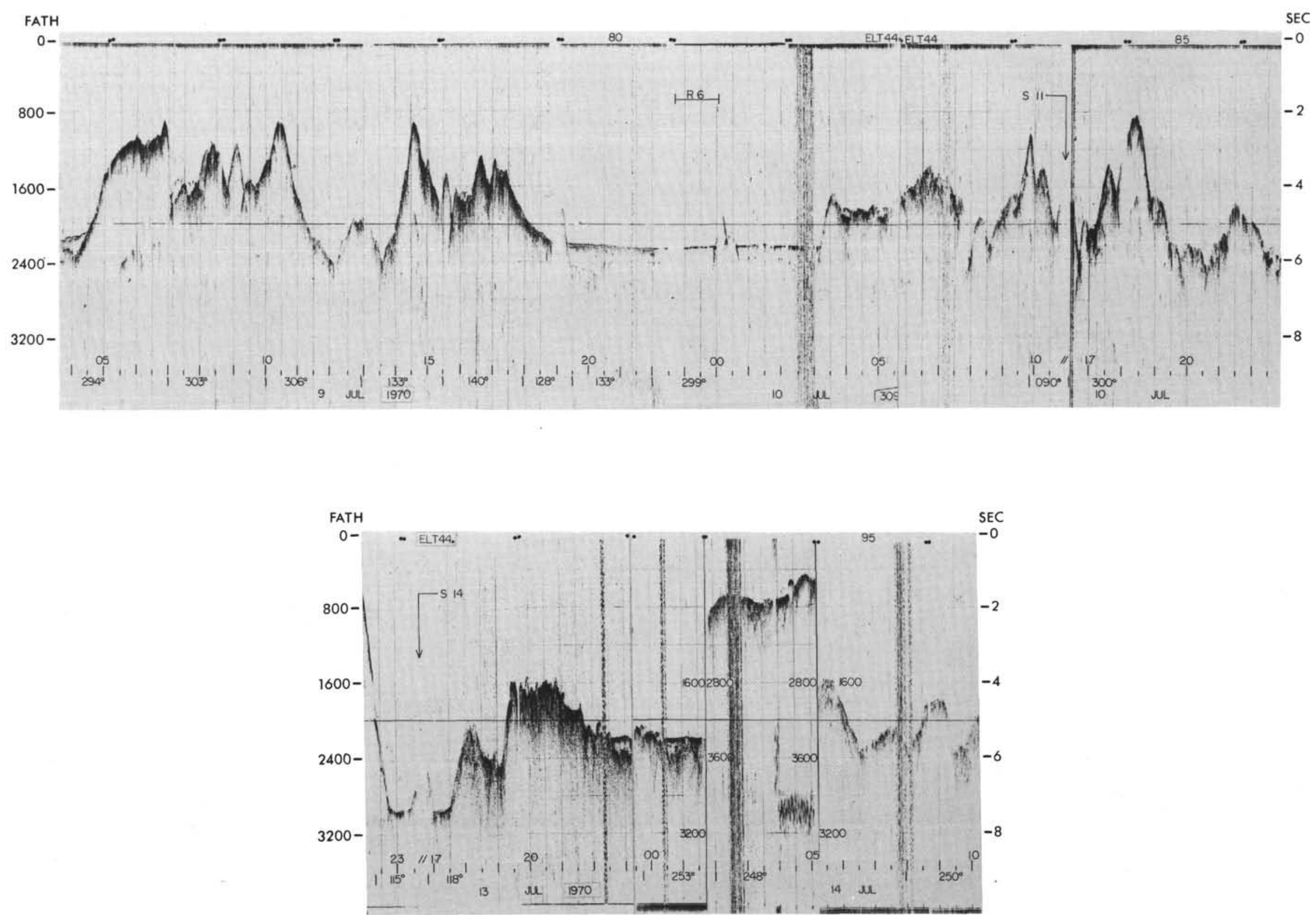

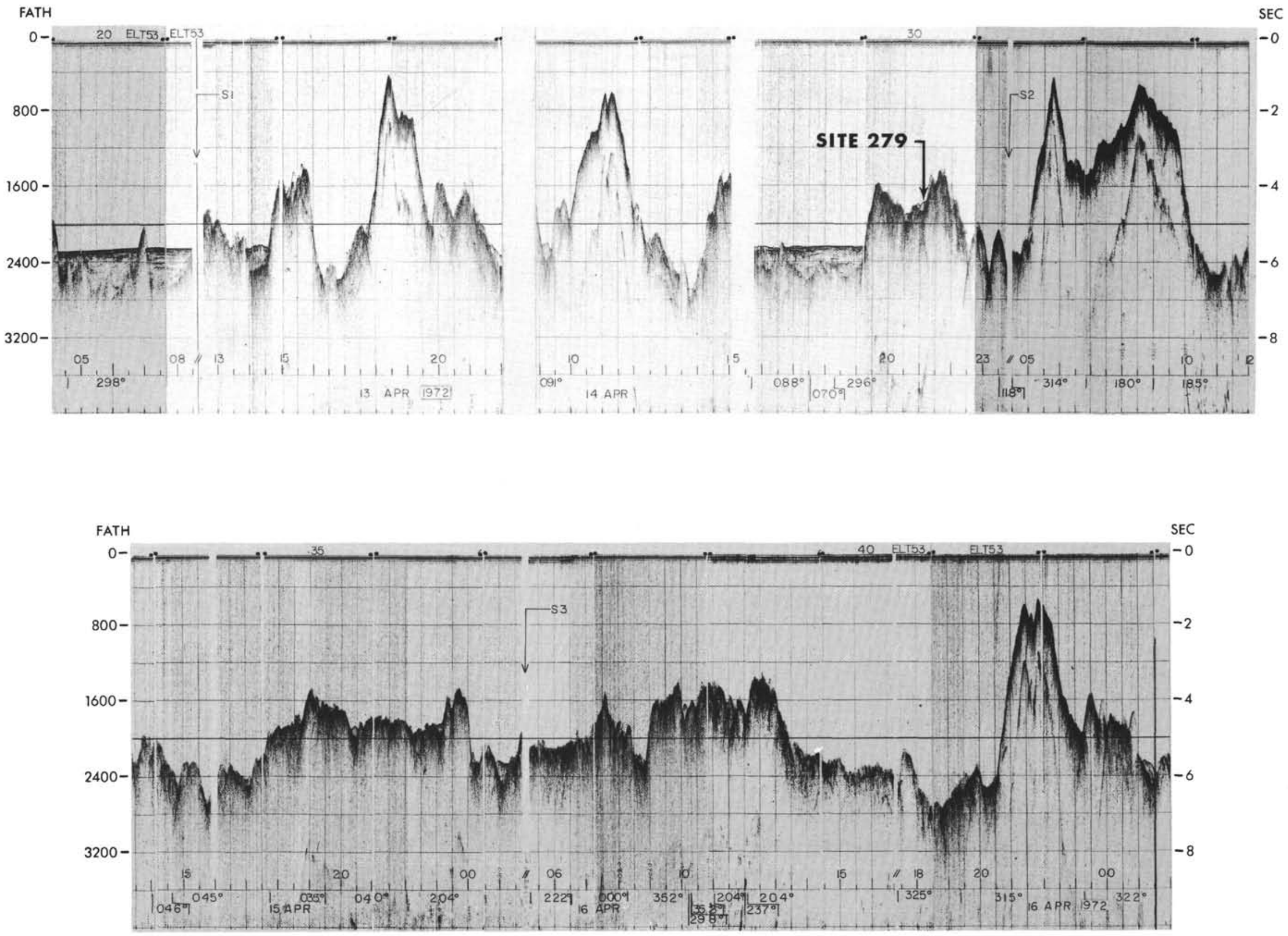

Figure 6c. Eltanin 53, $0400 \mathrm{hr}, 13$ April 1972 to $2200 \mathrm{hr}, 13$ April 1972; and $0900 \mathrm{hr}, 14$ April 1972 to $0130 \mathrm{hr}, 16$ April 1972. 


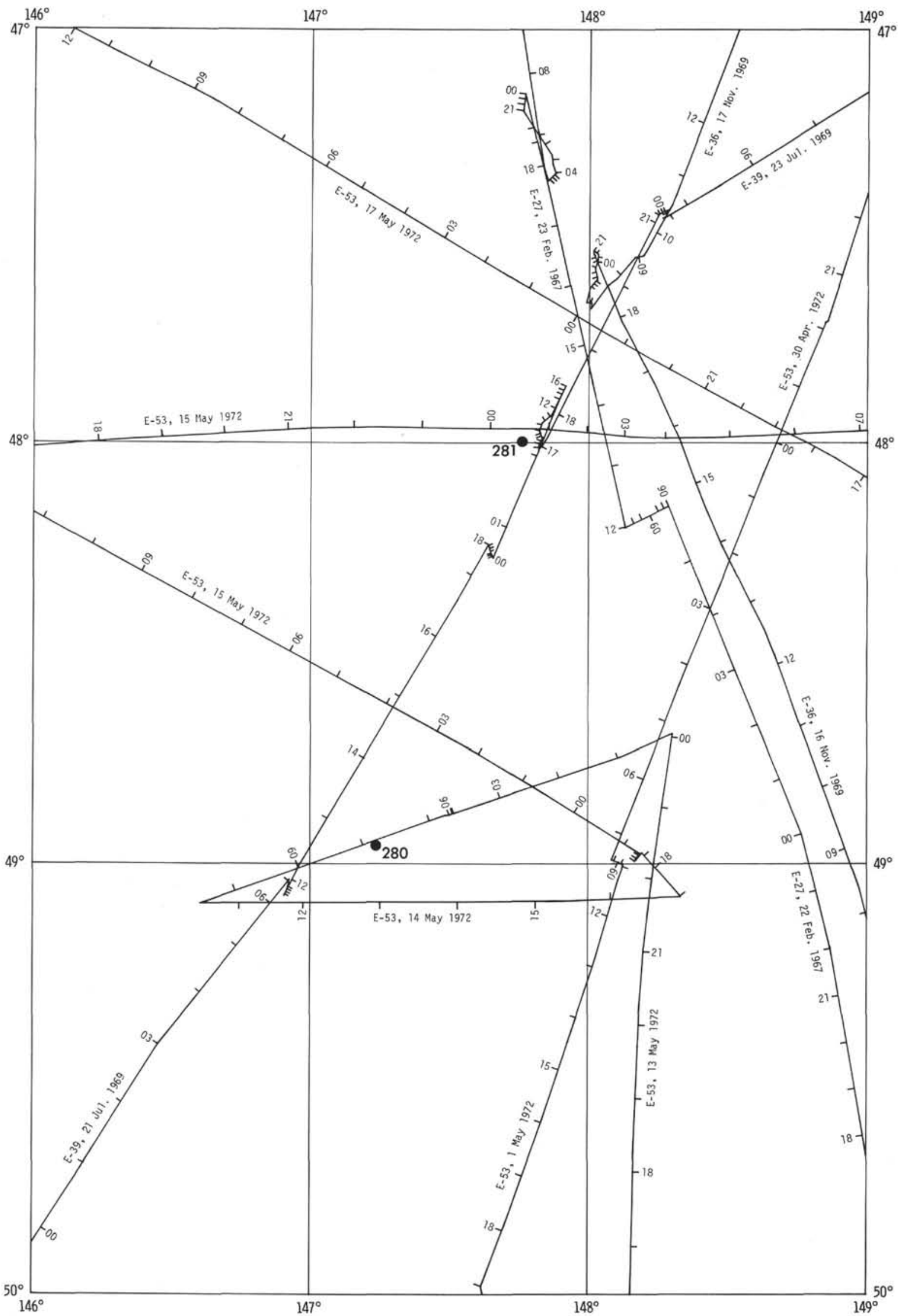

Figure 7. Track charts for Eltanin Cruises 27, 36, 39, and 53 in the vicinity of Sites 280 and 281, DSDP Leg 29. 
R. E. HOUTZ, T. D. AITKEN
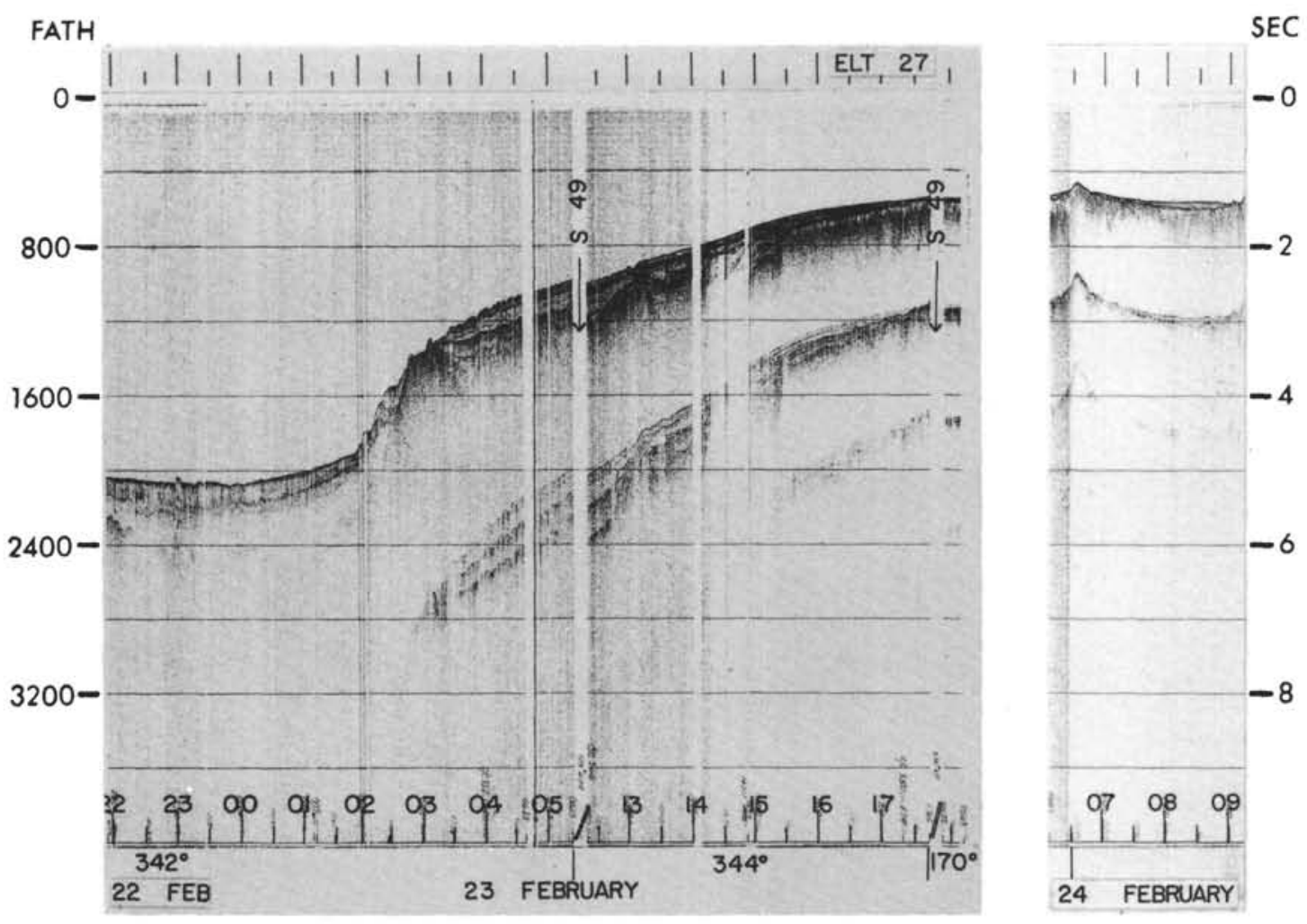

Figure 8. Eltanin 27, 36, 39, and 53 profiler records in vicinity of Sites 280 and 281, DSDP Leg 29. (a) Eltanin 27, 2200 hr, 22 February 1967 to 0900 hr, 24 February 1967.

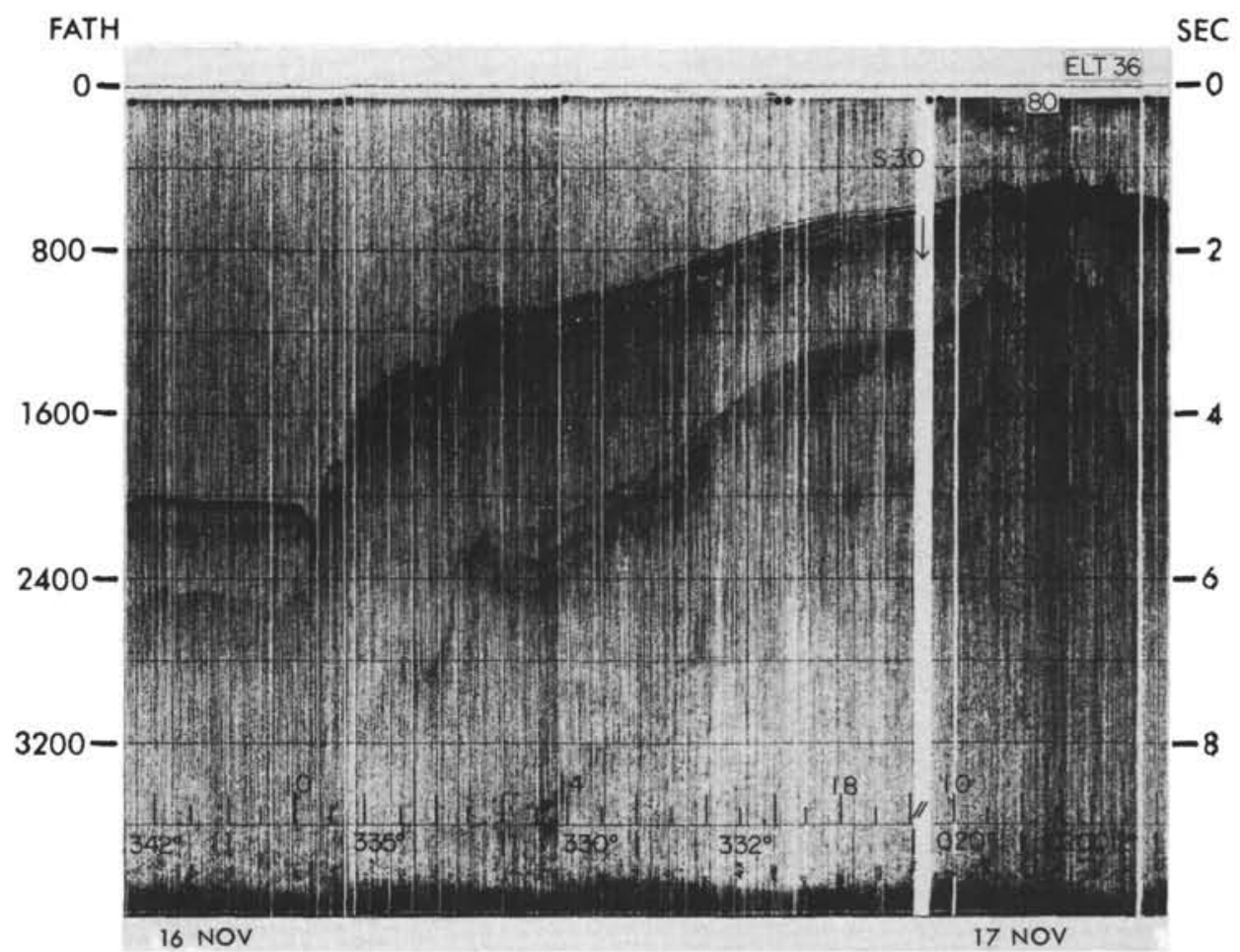

Figure 8b. Eltanin 36, $0800 \mathrm{hr}, 16$ November 1969 to $1300 \mathrm{hr}, 17$ November 1969. 

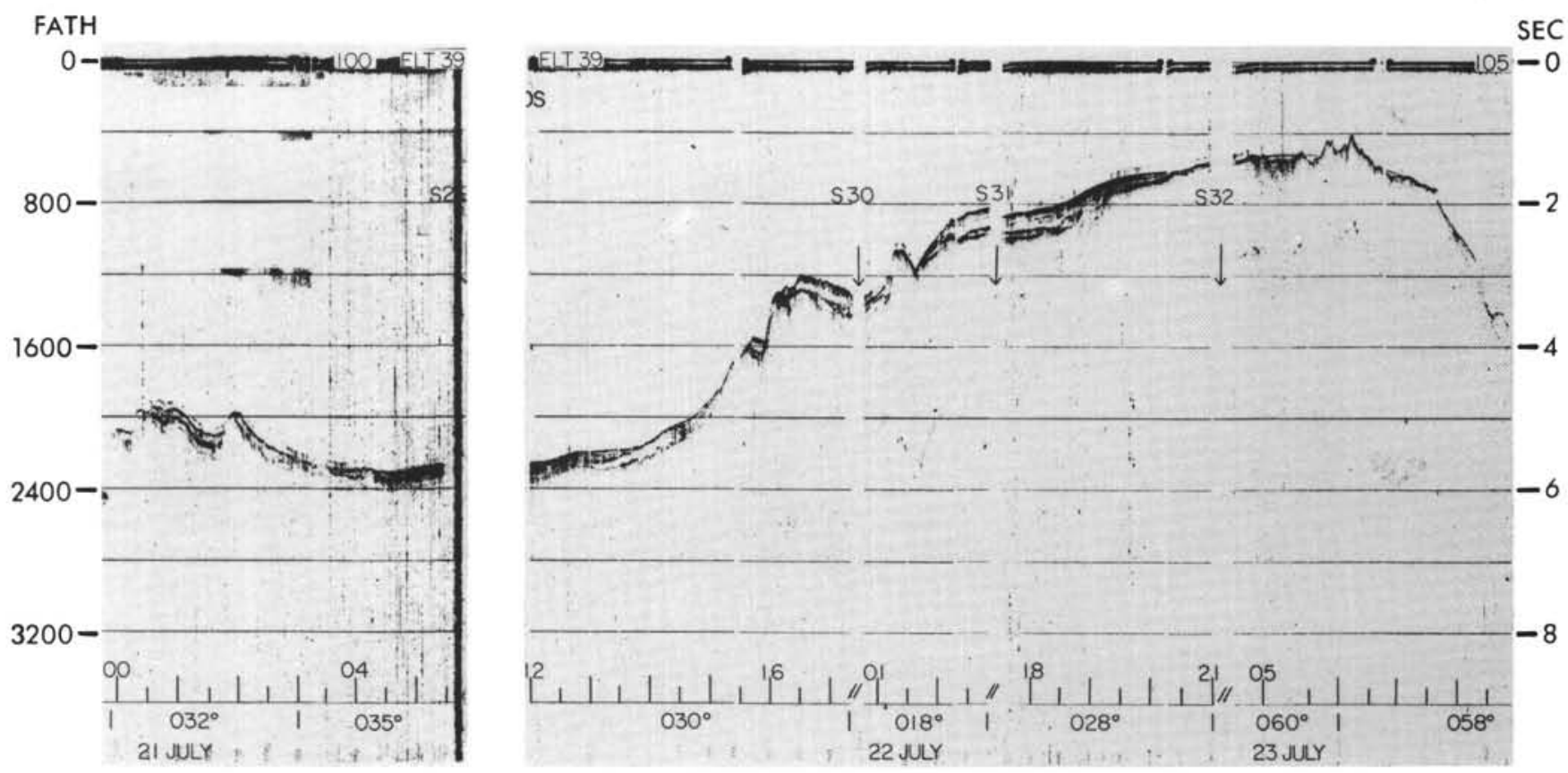

Figure 8c. Eltanin 39, 0000 hr, 21 July 1969 to 0800 hr, 23 July 1969. 

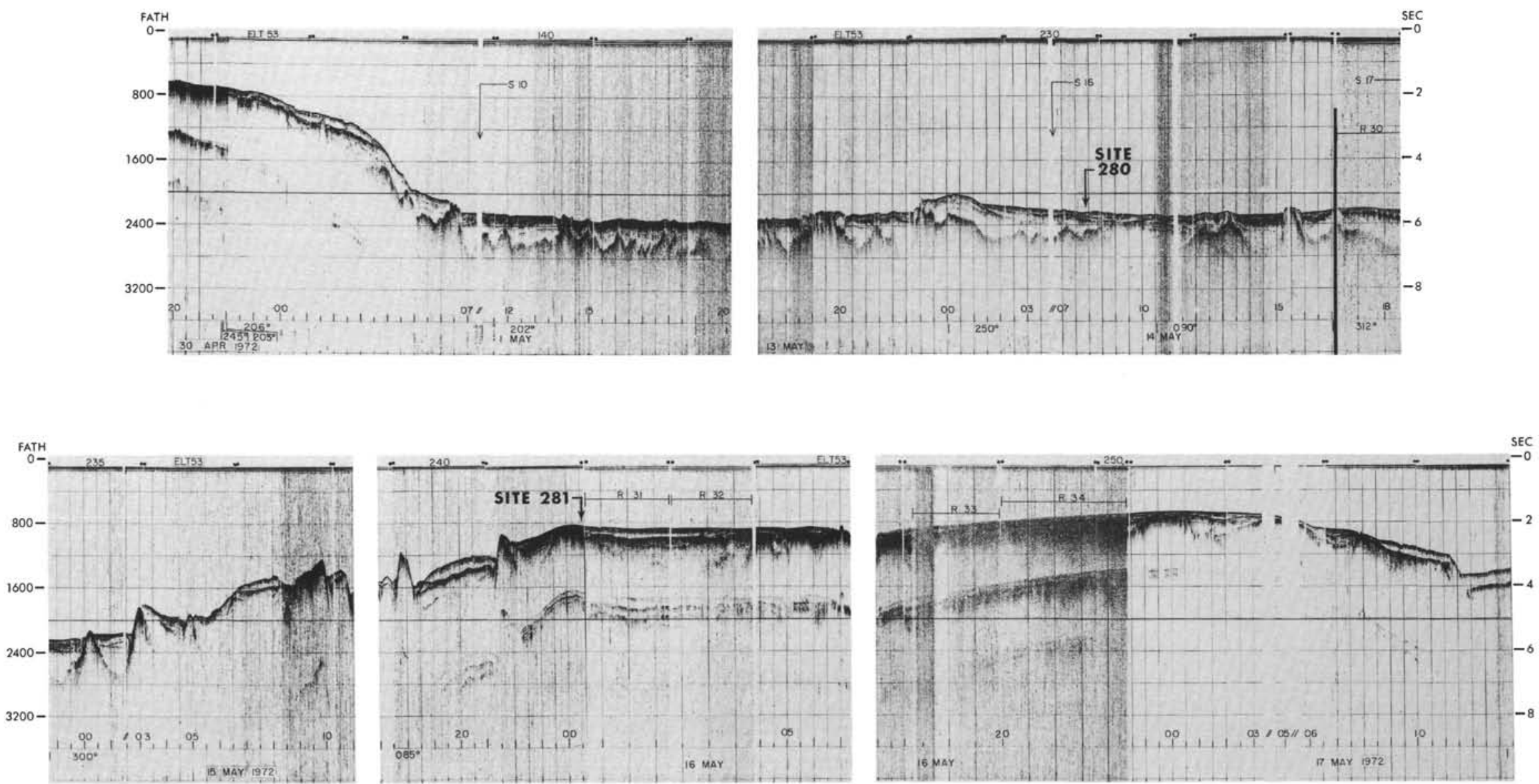

Figure 8d. Eltanin 53, 2000 hr, 30 April 1972 to 1900 hr, 1 May 1972; and 1700 hr, 13 May 1972 to 0700 hr, 16 May 1972. 


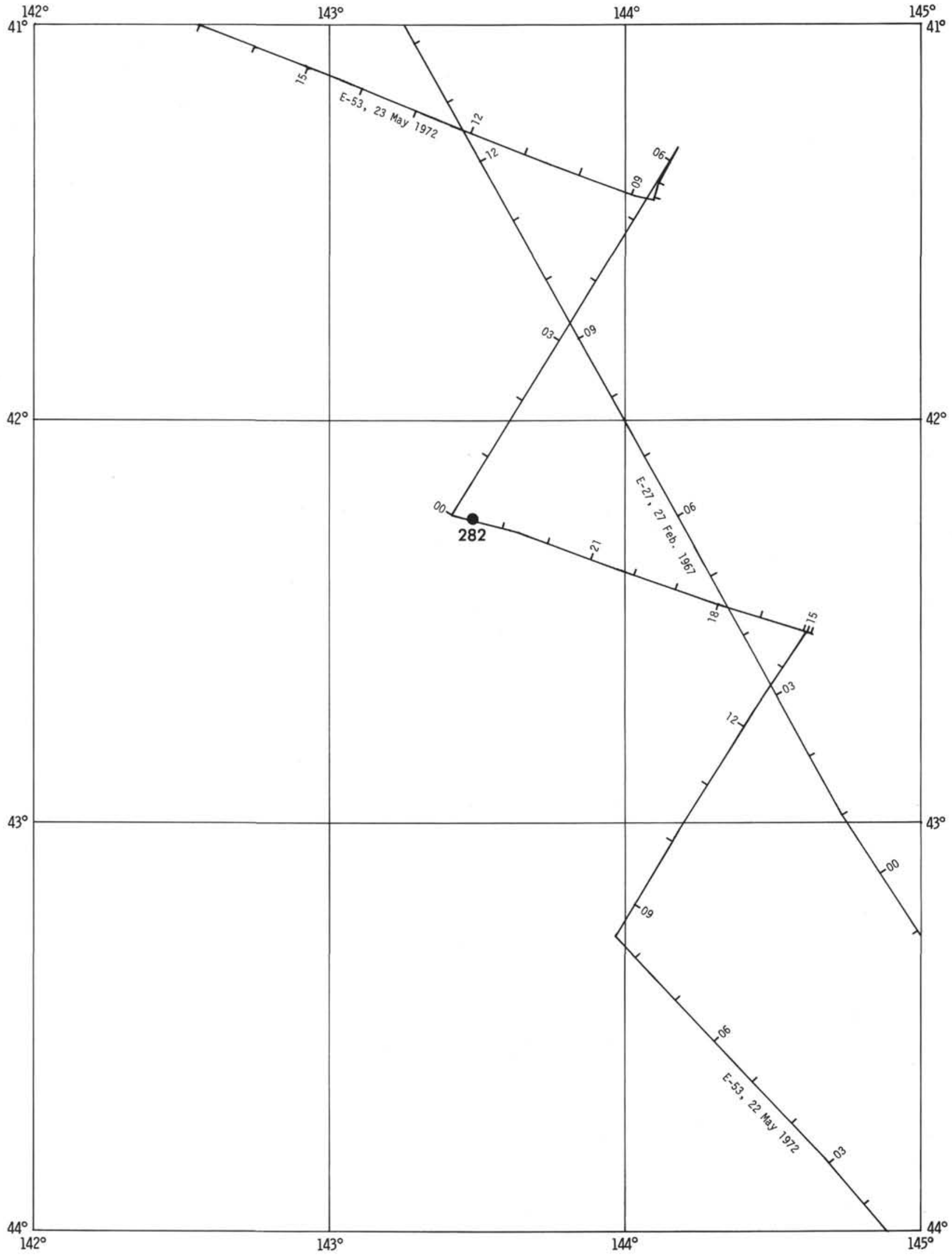

Figure 9. Track chart for Eltanin 27, 53 and Conrad 9 cruises in vicinity of Site 282, DSDP Leg 29. 
R. E. HOUTZ, T. D. AITKEN

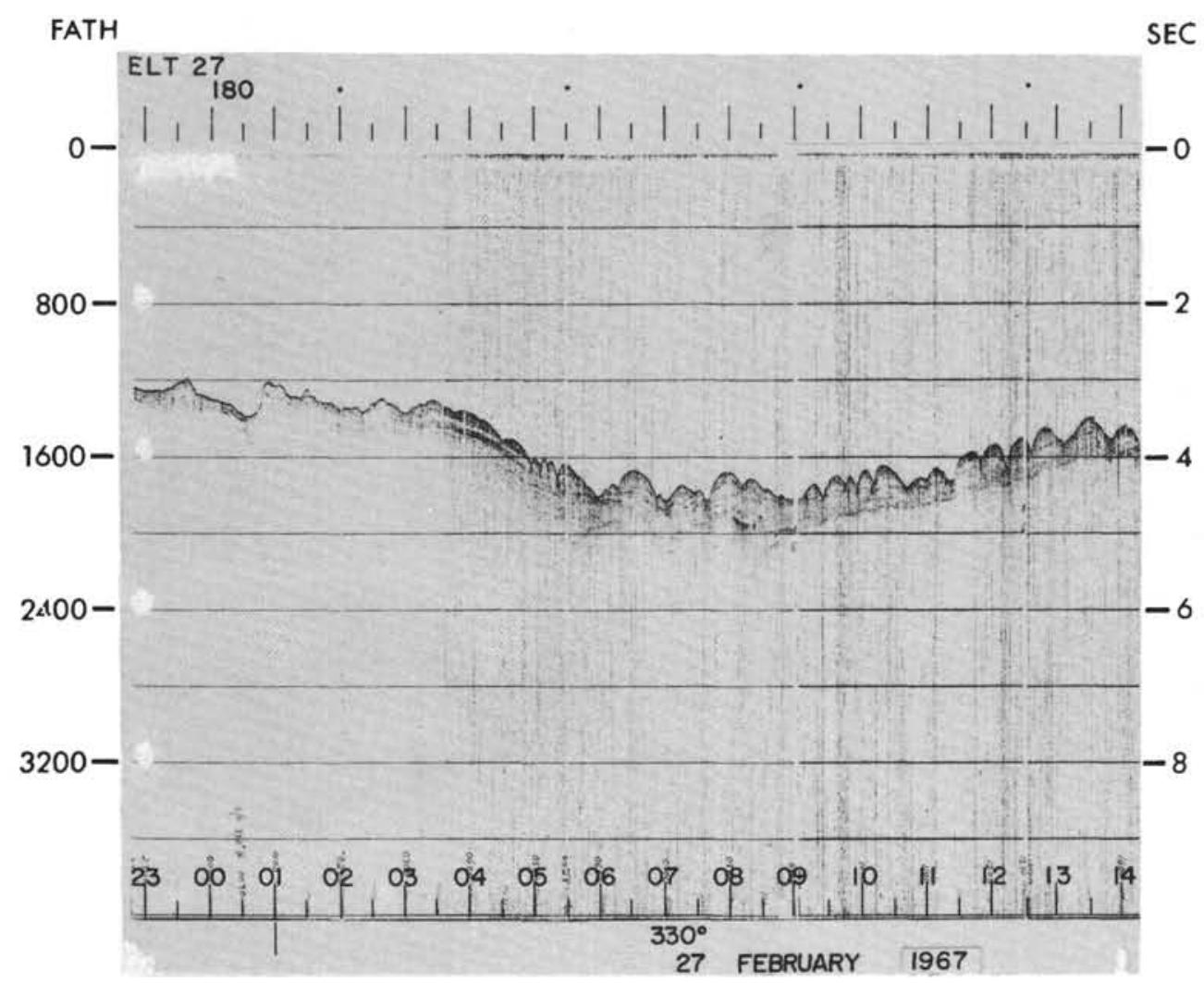

Figure 10. Eltanin 27, 53 and Conrad 9 profiler records in vicinity of Site 282, DSDP Leg 29. (a) Eltanin 27, $2300 \mathrm{hr}, 26$ February 1967 to $1400 \mathrm{hr}, 27$ February 1967.

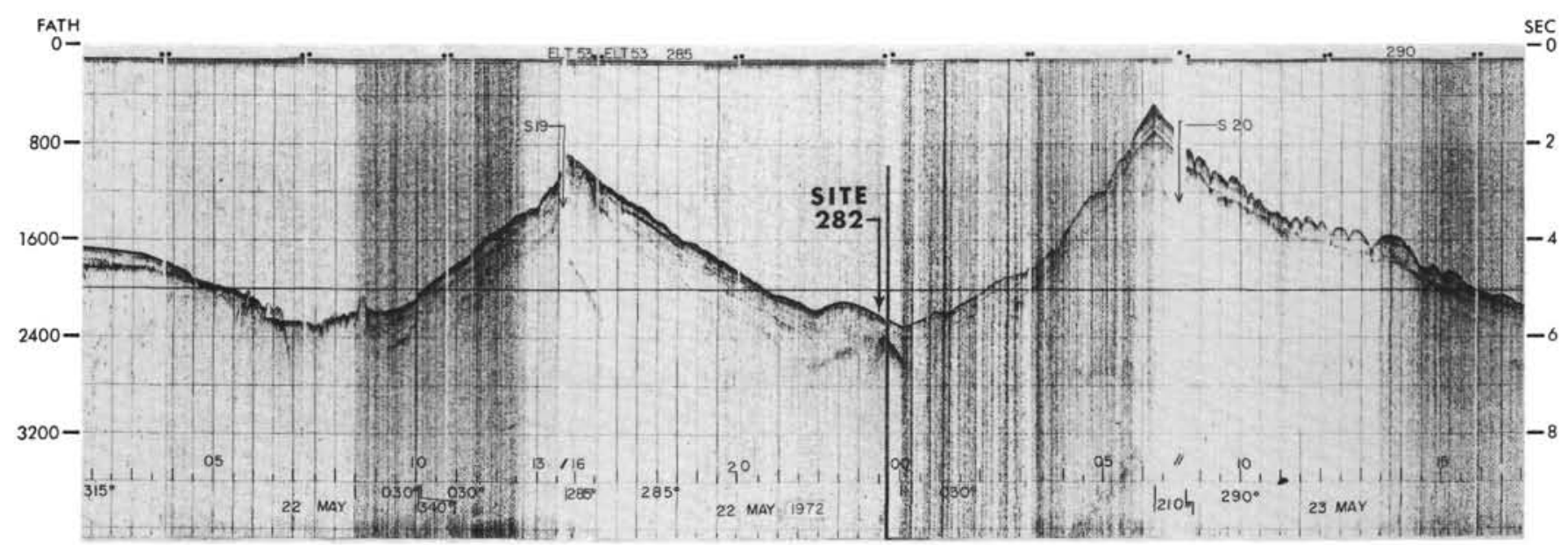

Figure 10b. Eltanin 53, $0200 \mathrm{hr}, 22$ May 1972 to $1700 \mathrm{hr}, 23$ May 1972. 


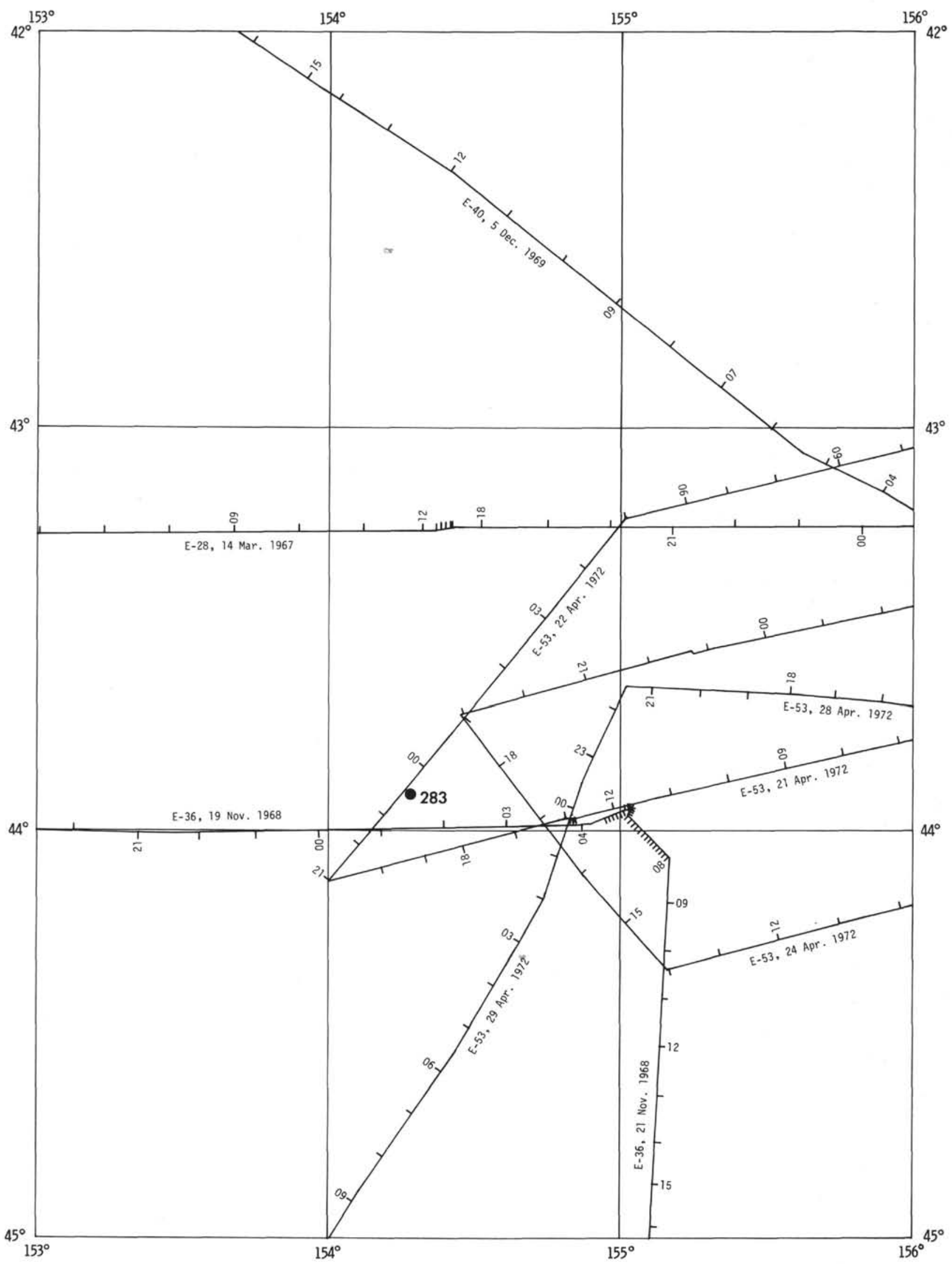

Figure 11. Track chart for Eltanin Cruises 28, 36, 40, and 53 in the vicinity of Site 283, DSDP Leg 29. 


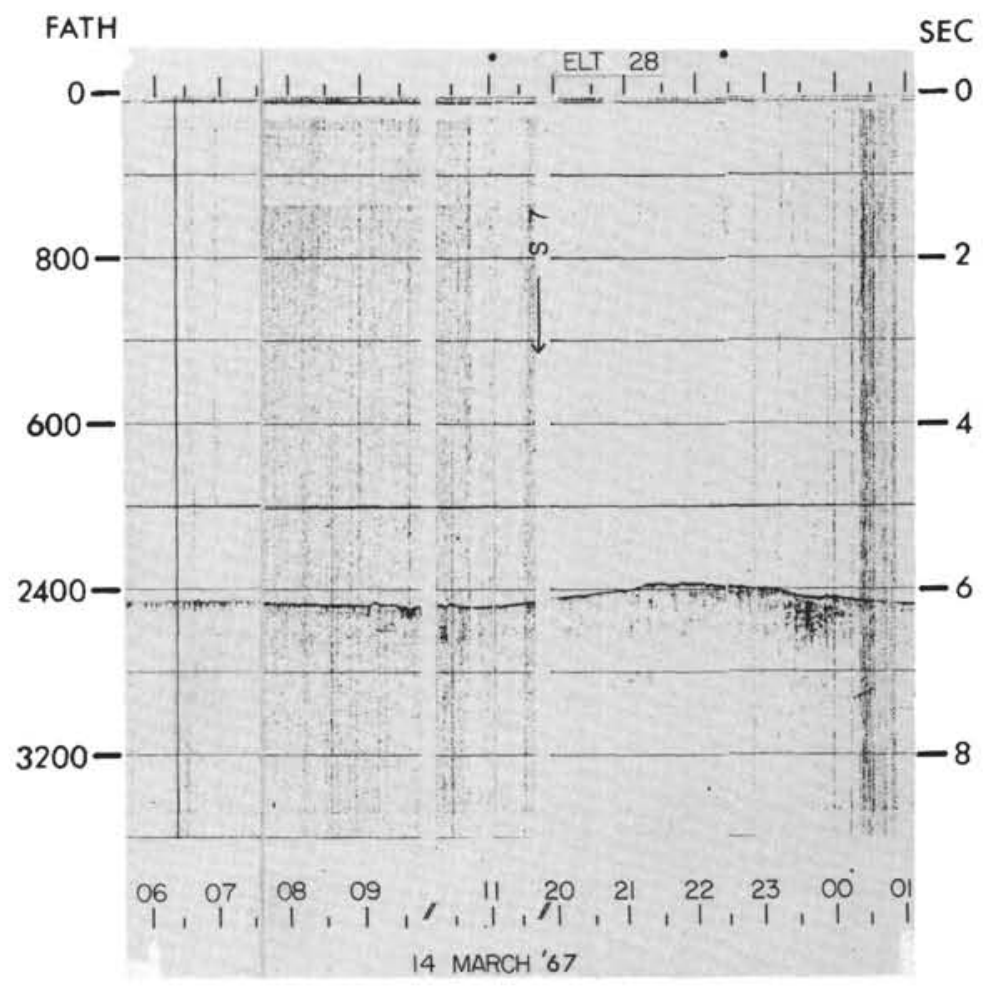

Figure 12. Eltanin $28,36,40$, and 53 profiler records in the vicinity of Site 283, DSDP Leg 29. (a) Eltanin 28, $0600 \mathrm{hr}, 14$ March 1967 to $0100 \mathrm{hr}, 15$ March 1967.

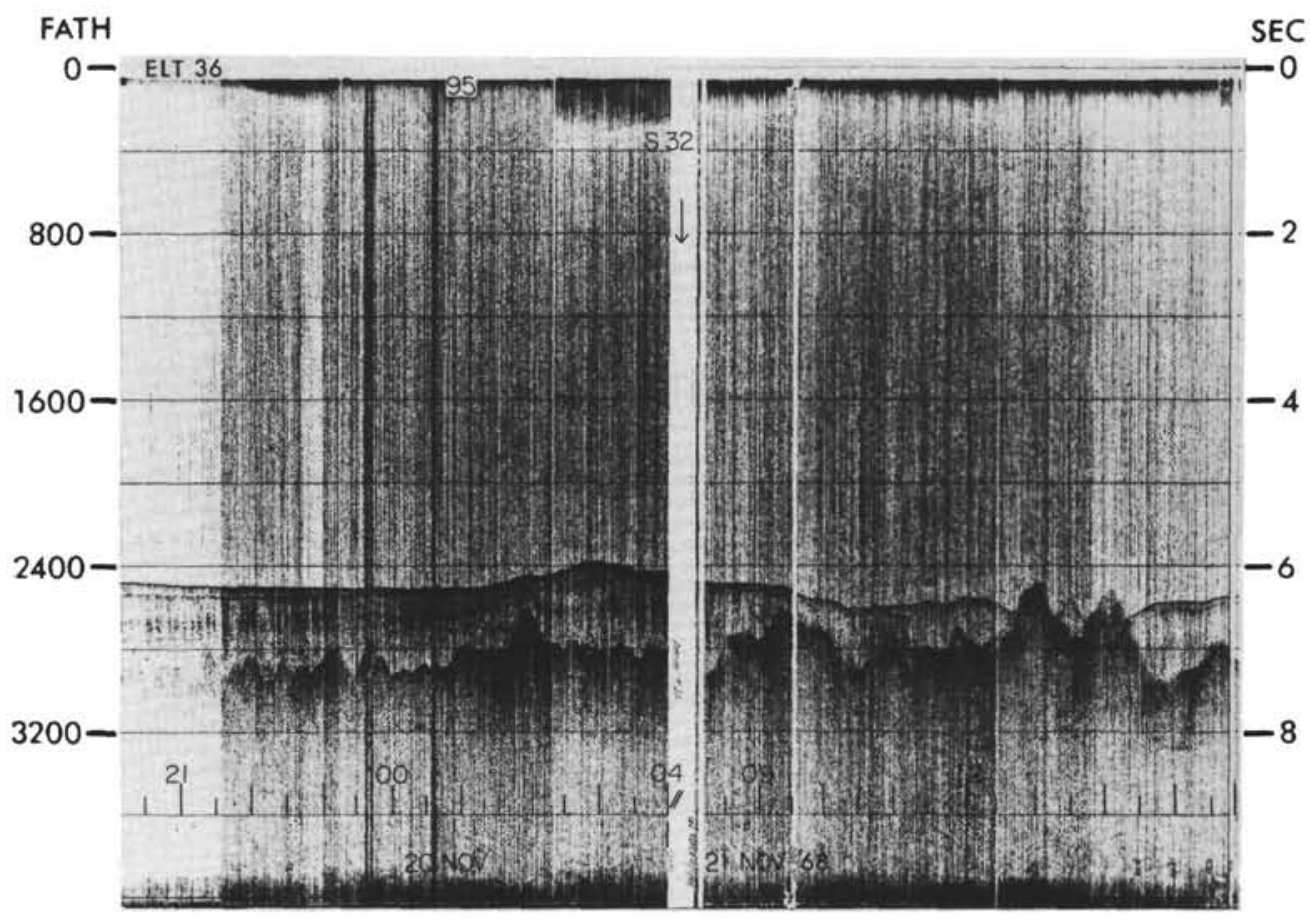

Figure 12b. Eltanin 36, 2000 hr, 19 November 1968 to 1600 hr, 21 November 1968. 


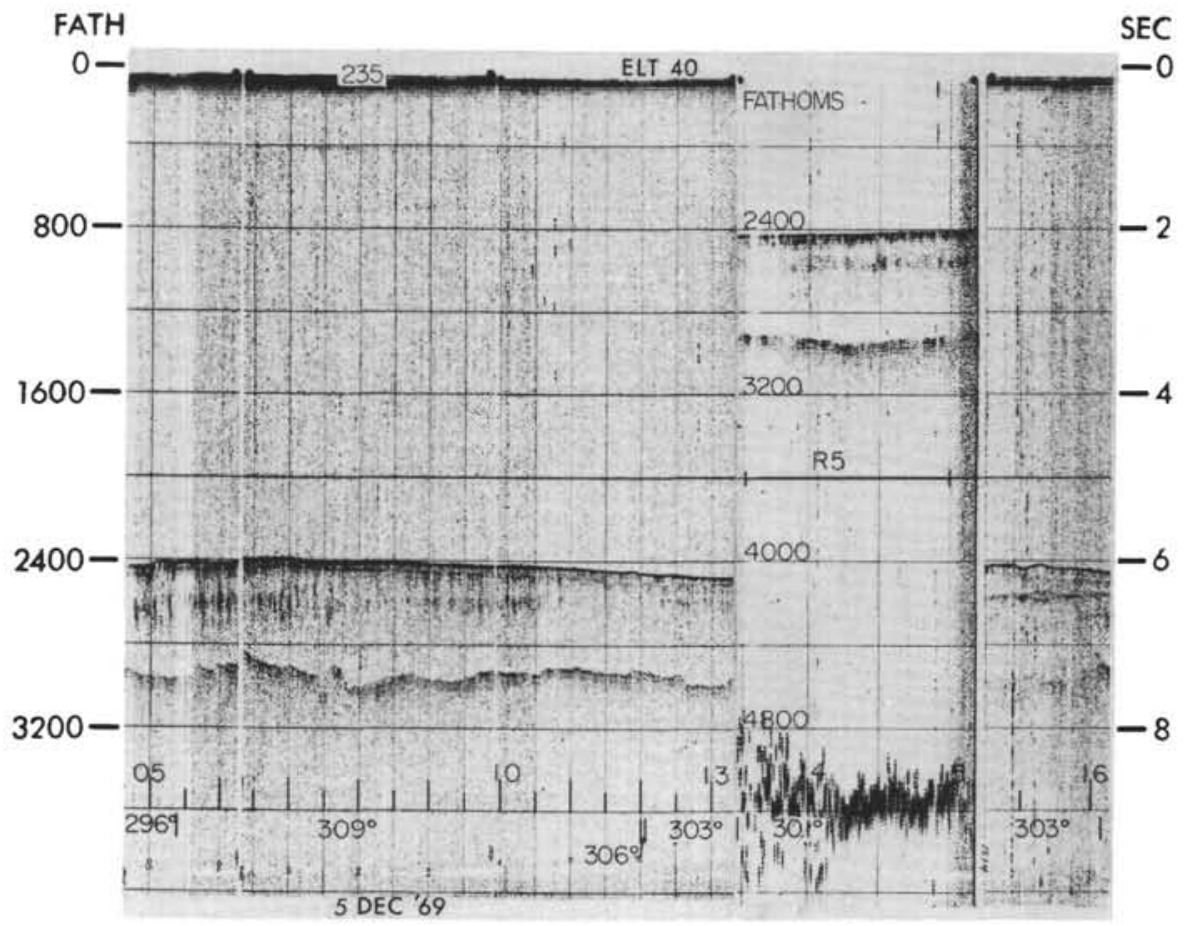

Figure 12c. Eltanin 40, 0440 hr, 5 December 1969 to 1600 hr, 5 December 1969. 
FATH

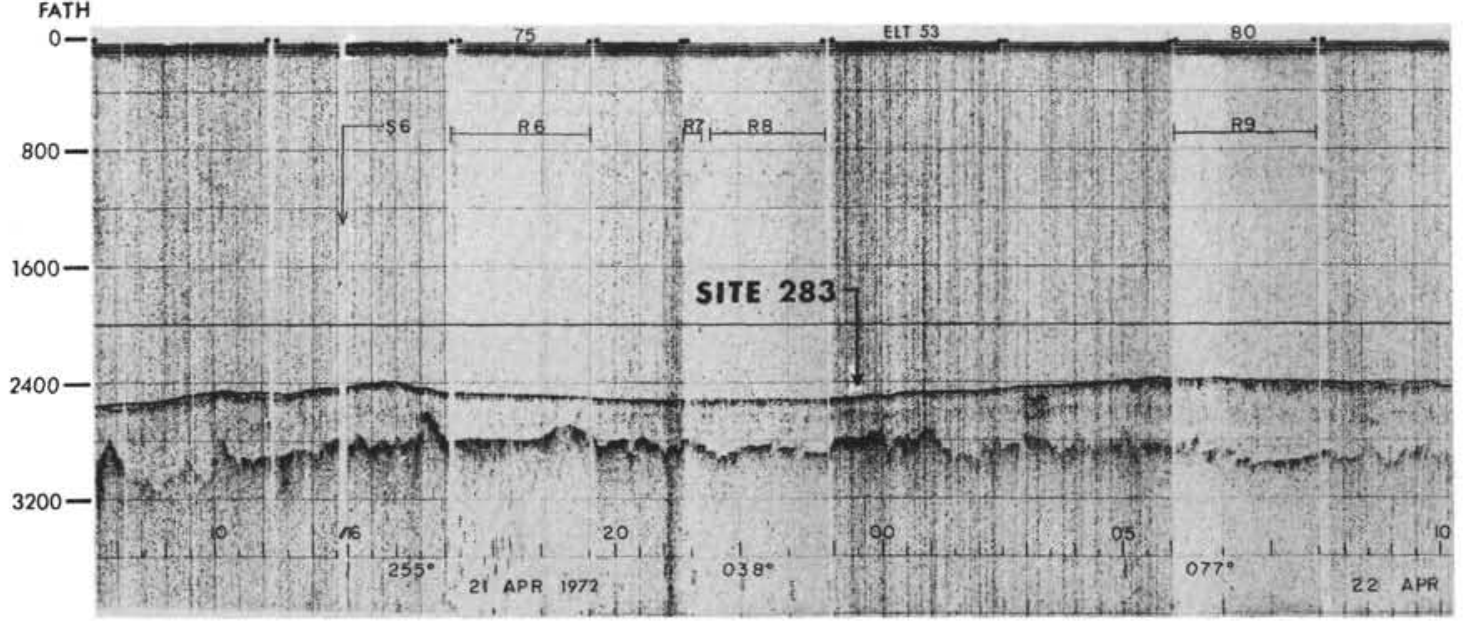

SEC
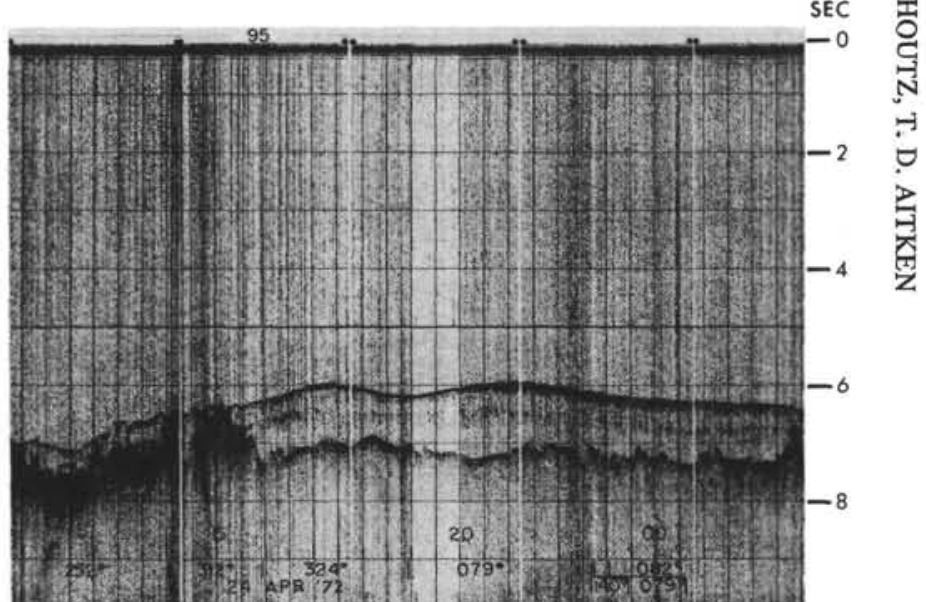

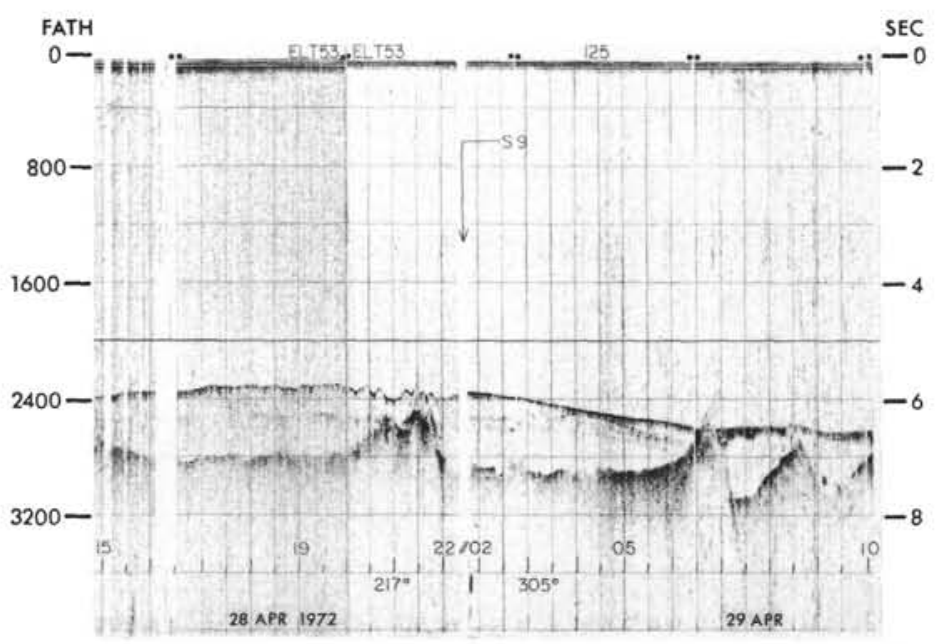

Figure 12d. Eltanin 53, $0730 \mathrm{hr}, 21$ April 1972 to $1000 \mathrm{hr}, 22$ April 1972; and $1040 \mathrm{hr}, 24$ April 1972 to $0230 \mathrm{hr}, 25$ April 1972; and $1530 \mathrm{hr}, 28 \mathrm{April} 1972$ to 0930 hr, 29 April, 1972. 


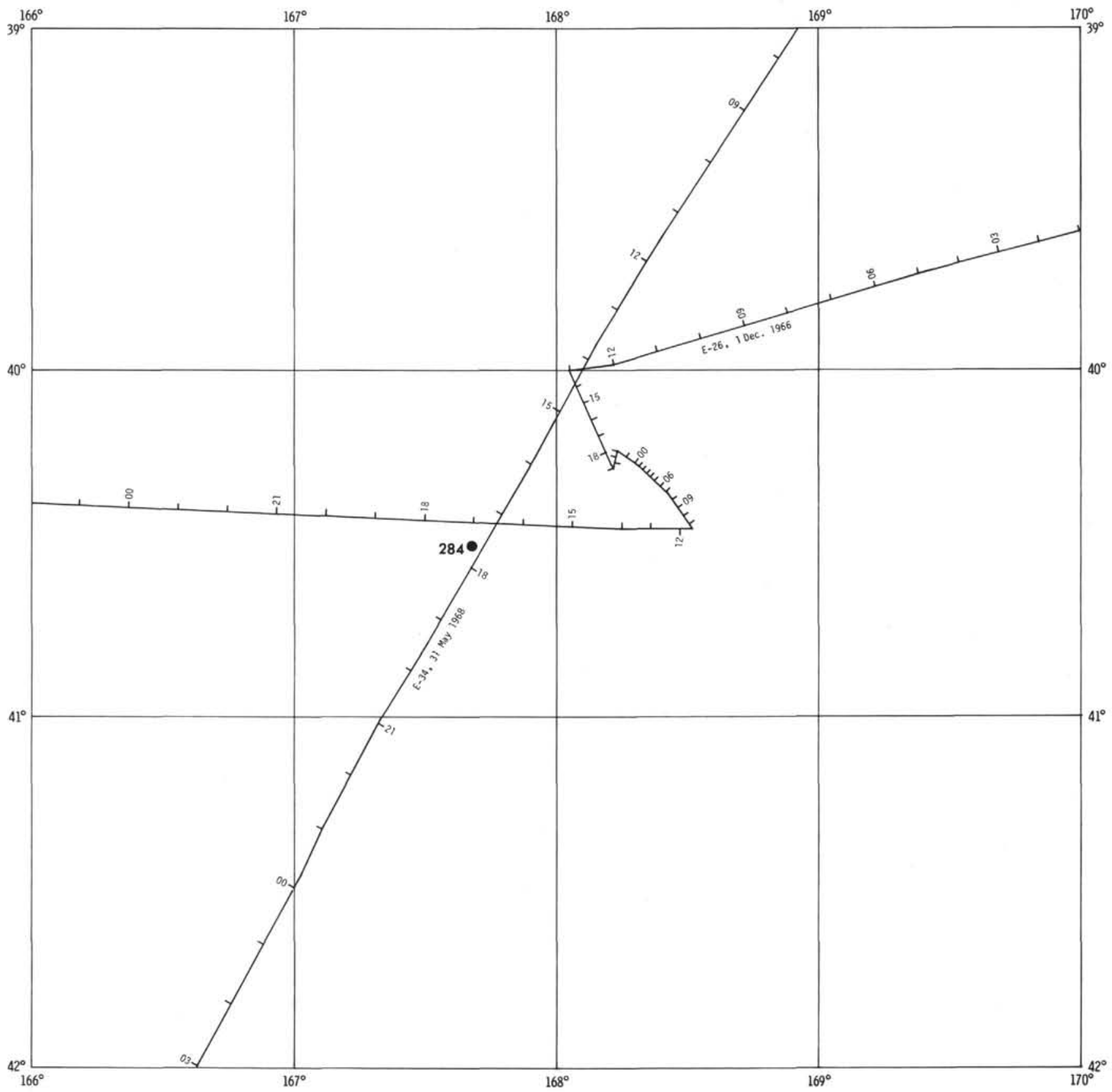

Figure 13. Track chart for Eltanin Cruises 26 and 34 in vicinity of Site 284, DSDP Leg 29. 


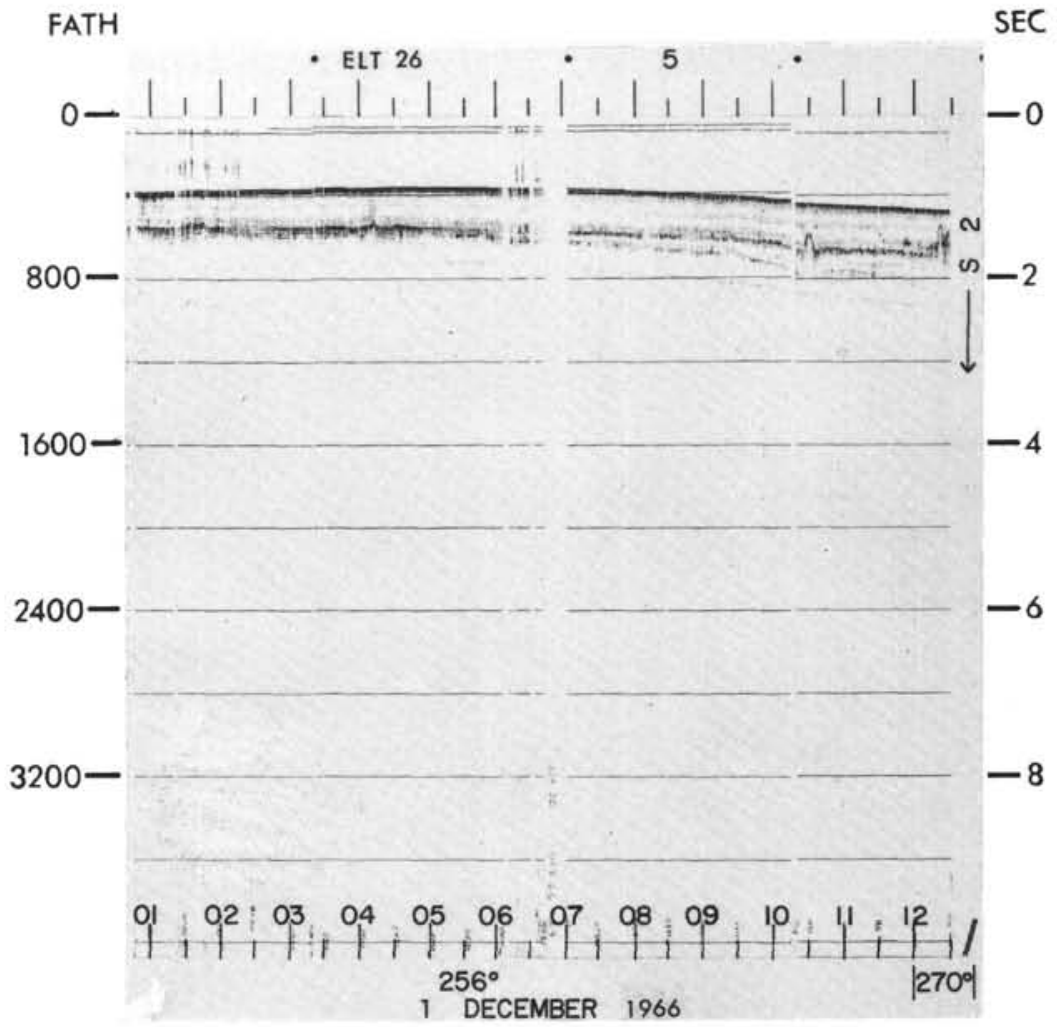

Figure 14. Eltanin 26 and 34 profiler records in vicinity of Site 284, DSDP Leg 29. (a) Eltanin 26, $0100 \mathrm{hr}, 1$ December 1966 to $1230 \mathrm{hr}, 1 \mathrm{De}$ cember 1966.

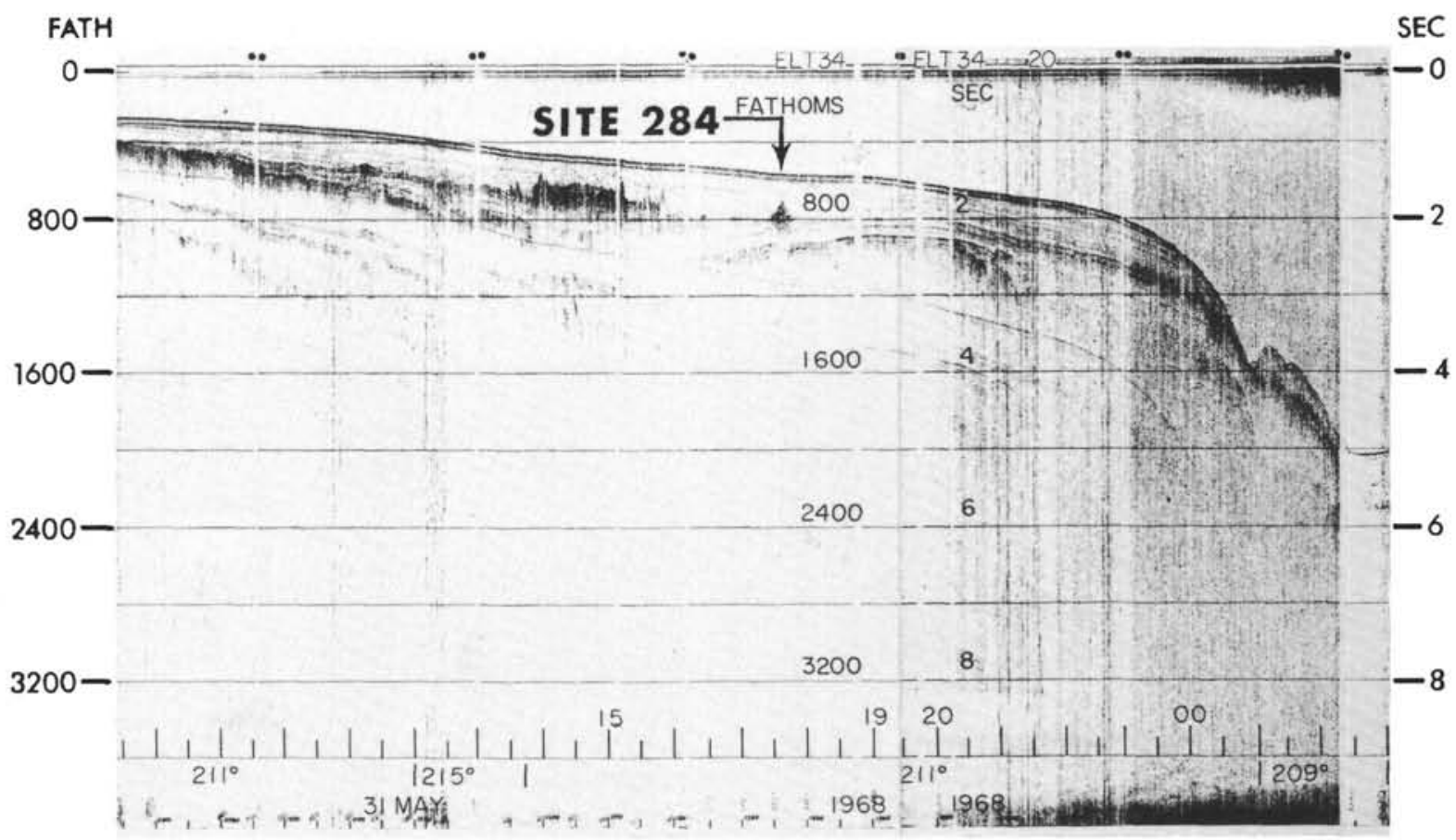

Figure 14b. Eltanin 34, $0730 \mathrm{hr}, 31$ May 1968 to $0300 \mathrm{hr}, 1 \mathrm{June} 1968$. 